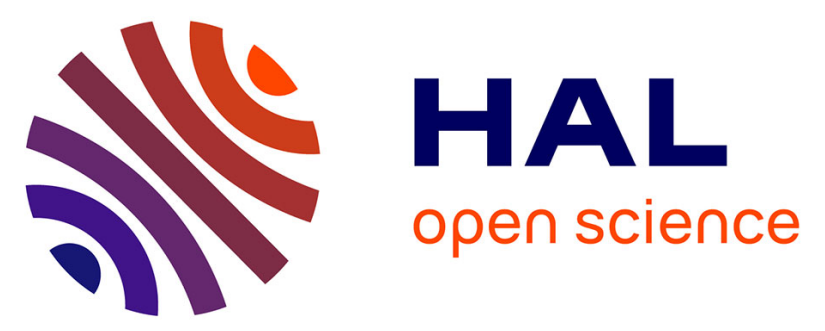

\title{
Late Quaternary environmental changes of Lake Urmia basin (NW Iran) inferred from sedimentological and magnetic records.
}

Alina Tudryn, Seyed-Hani Motavalli-Anbaran, Piotr Tucholka, E. Gibert, Mohammad Lankarani, Hesam Ahmady-Birgani, Ting Kong, Aurélie Noret, Serge Miska, Marc Massault, et al.

\section{To cite this version:}

Alina Tudryn, Seyed-Hani Motavalli-Anbaran, Piotr Tucholka, E. Gibert, Mohammad Lankarani, et al.. Late Quaternary environmental changes of Lake Urmia basin (NW Iran) inferred from sedimentological and magnetic records.. Quaternary International, 2021, 589, pp.83-94. 10.1016/j.quaint.2021.03.024 . hal-03454996

\section{HAL Id: hal-03454996 https://hal.science/hal-03454996}

Submitted on 29 Nov 2021

HAL is a multi-disciplinary open access archive for the deposit and dissemination of scientific research documents, whether they are published or not. The documents may come from teaching and research institutions in France or abroad, or from public or private research centers.
L'archive ouverte pluridisciplinaire HAL, est destinée au dépôt et à la diffusion de documents scientifiques de niveau recherche, publiés ou non, émanant des établissements d'enseignement et de recherche français ou étrangers, des laboratoires publics ou privés. 
1 Late Quaternary environmental changes of Lake Urmia basin (NW Iran) inferred from

2 sedimentological and magnetic records

3

4 Alina Tudryn ${ }^{1, *}$, Seyed-Hani Motavalli-Anbaran ${ }^{2}$, Piotr Tucholka $^{1}$, Elisabeth Gibert-Brunet ${ }^{1}$,

5 Mohammad Lankarani ${ }^{3}$, Hesam Ahmady-Birgani ${ }^{4}$, Ting Kong ${ }^{1}$, Aurélie Noret ${ }^{1}$, Serge Miska ${ }^{1}$,

6 Marc Massault ${ }^{1}$, Olivier Dufaure ${ }^{1}$

$7 \quad{ }^{1}$ University Paris-Saclay, CNRS, UMR 8148-GEOPS, 91405, Orsay, France

$8 \quad{ }^{2}$ Institute of Geophysics, University of Tehran, Tehran, Iran

$9{ }^{3}$ School of Geology, University-College of Science, University of Tehran, Tehran, Iran

$10{ }^{4}$ Faculty of Natural Resources, Urmia University, Urmia, Iran

11

$12{ }^{*}$ Corresponding author

13 E-mail address: alina.tudryn@universite-paris-saclay.fr 


\section{Abstract}

17

The ongoing changes affecting Lake Urmia (NW Iran) are revealed by the lake water level decrease $(\sim 7 \mathrm{~m}$ in the last $20 \mathrm{yr})$ that was attributed to natural and anthropogenic causes but the exact impact of these factors on the state of the lake is still not identified. Indeed, lack of detailed record of environmental evolution of the lake in the past limits the understanding of actual and future processes. Our project aims to obtain a high-temporal resolution record of environmental changes in the lake area for the last 30 kyrs. Sediment cores have been obtained from the recently dried out part of the lake near Urmia City, and surface and ground waters have been measured for electric conductivity. This paper presents results of water and sediments analyses. Six ${ }^{14} \mathrm{C}$ AMS dating on organic fractions provide a chronological framework and indicate that the record covers the last $\sim 30$ cal kyr BP. During this period, evaporitic conditions were prevailing in the lake. The electric conductivity of brines from the sediment highlights changes in the lake water salinity. The data indicate a lake-level low stand at $\sim 30$ cal kyr BP that was followed by a water level rise and establishment of lacustrine conditions for the next $\sim 9 \mathrm{kyr}$, this phase representing the highest lake level recorded since that time to date. From the LGM, the lake experienced several fluctuations of the water level. The relatively long-term lacustrine condition established during the Early Holocene before the water level decrease between 5.5-4.9 cal kyr BP. Sediments from the two dry events at $\sim 30 \mathrm{cal}$ kyr BP and at 5.5-4.9 cal kyr BP are characterized by the presence of greigite, which indicates anaerobic early diagenetic conditions in the sediment.

Keywords: Lake Urmia; Late Quaternary palaeoenvironments; Water level change; Carbonates; Magnetic minerals; Electric conductivity 
39

40

41

\section{Introduction}

Registered in the International Ramsar Convention and National Park in NW Iran, Lake Urmia (Fig.1) is one of the largest saline lakes in the world displaying a unique, highly valuable biodiversity (Asem et al., 2014). The lake plays a major role in creating the mild climate favouring a highly productive agriculture and brine shrimp farming, both making the region as one of the most important economical poles of Iran. However, since the end of the 1990's, Lake Urmia's water level dropped drastically, and by more than $7 \mathrm{~m}$ during the last 20 years (Fig. 1b) causing water hyper salinization, desertification and dust storms threatening health condition of millions of people at a regional scale (Alipour, 2006; Pengra, 2012; Ahmady-Birgani et al., 2018; 2020). Although, subjected to controversies, the water level fall has been attributed to rainfall declining by $\sim 10 \%$ and to anthropogenic causes such as the construction of many dams on rivers feeding the lake (Fig.1c) and intense groundwater pumping (Alipour, 2006; Pengra, 2012; Jalili et al., 2016; Sharifi et al., 2018).

Despite evident water overexploitation, the role of natural versus anthropogenic factors influencing the lake hydrology is still not quantified. The lack of detailed records of environmental evolution in the past limits the understanding of actual processes and the capability to develop integrated management of this water resource. As a matter of fact, the lake deposits have not been extensively explored for palaeoenvironmental reconstructions. Already existing sedimentological, geochemical and pollen studies of Pleistocene and Holocene sequences are scarce. They cover large time scale $(200 \mathrm{kyr})$ with a low resolution, generally missing the Holocene (Djamali et al., 2008a, 2008b, 2010; Stevens et al., 2012) or focus on the Holocene with a low temporal resolution (Kelts and Shahrabi, 1986; Bottema, 1986), or just concern its youngest part (Talebi et al., 2015). However, all these studies show the highest amplitude lake-level variations at a glacial-interglacial time scale with a dry open mountain steppe dominating during the glacial periods and a steppe-forest environment during interglacials. An increase in tree pollens during the Holocene was recorded at the transition from Early to Mid-Holocene, at $6.5 \mathrm{kyr}$ 
65 B.P., and similar to today's vegetation established. The vegetation reached its maximum 66 destruction due to increasing human impact during the last centuries. Saline deposition seems

67 almost continuous during the Holocene with clear water level changes but no visible total 68 desiccation of Lake Urmia.

69 The Franco-Iranian project initiated by bilateral Gundishapur program (2016-2017) on Lake

70 Urmia aims to obtain high temporal resolution records of past environmental and climate changes

71 in the SW lake area for the Late Pleistocene and Holocene, and to identify natural and human

72 impacts on the past hydro-environments of the lake and its catchment area. The process integrates

73 hydrogeological, hydrogeochemical and lake sediments studies. The obtained results will be

74 useful for the integrated approach of future Lake Urmia management and restoration of its

75 environment, and for studies of the past climate evolution at a larger, south Eurasian scale.

76 Indeed, the area is a place of choice being on the junction of the different air mass circulation

77 systems from the West (Atlantic, Mediterranean and North Sea) and from the East (Siberian and

78 Indian monsoon).

79 In this paper are presented the first results of water in-situ measurements (electric conductivity,

$80 \mathrm{pH}$ and temperature) and measurements on five collected sediment cores. The chronological

81 framework is based on $\operatorname{six}{ }^{14} \mathrm{C}$ datings. The sedimentary sequence has been analysed for water

82 contents in sediment and corresponding relative salinity, grain size, magnetic minerals,

83 mineralogy of bulk sediment by X-Ray diffraction (XRD) and carbonate contents and

84 mineralogy. The goal of the study is (i) to provide the record of environmental changes in Lake

85 Urmia basin, mainly in terms of the lake water changes for the last $\sim 30$ cal kyr BP., (ii) to

86 complement the existing information on the evolution of the lake basin at the local scale and that

87 of the Middle East, and (iii) to contribute to a better understanding of relation between local

88 environment and the climate change. 
91 Lake Urmia is an endorheic hypersaline lake located in a subsiding tectonic basin (Berberian and 92 Arshani, 1975) in NW Iran (Fig. 1). Before the recent water level fall, it was the largest lake in 93 the region after the Caspian Sea and the second largest salt lake on Earth, and presented similar in 94 physical, chemical and biological aspects to the Great Salt Lake in the USA (Kelts and Shahrabi, 95 1986). Lake Urmia was approximately $140 \mathrm{~km}$ long and $85 \mathrm{~km}$ wide, with a deeper northern 96 basin (maximal depth of $\sim 16 \mathrm{~m}$ ) and shallower southern one, salinity varying between 140 and 97 more than 220 g. $\mathrm{L}^{-1}$ on an annual basis, a surface area of 5,000 to $6,000 \mathrm{~km}^{2}$ and a catchment area 98 of approximately 52,500 $\mathrm{km}^{2}$ (Sharifi et al., 2018). Although its salinity varied between 140 and 99 more than 220 g.L $\mathrm{L}^{-1}$ on an annual basis, the lake was geochemically homogeneous due to mixing 100 by strong water currents, particularly during spring (Alipour, 2006, Sharifi et al., 2018). 101 Nevertheless, Sharifi et al. (2018) show that in spring, the hydrochemistry of the southern part of 102 the lake at the vicinity of Simineh Rud and Zarrineh Rud river mouths (Fig. 1) becomes different 103 due to fresh water inflow to the lake, some stratification in water column was also observed 104 (report by Azarbaidjan Regional Mining Cooperation, 1995). Lately, both basins were separated 105 by the Kalantari causeway, an east-west dike-type highway constructed in the 1980s - 1990s that stretches on $15 \mathrm{~km}$ across the center of the lake with a gap of $\sim 1.5 \mathrm{~km}$ on which a bridge was constructed (1998-2008).

The lake basin is situated in a semi-arid zone. Prevailing winds are westerlies during winter, northeasterlies during summer and strong southwesterlies during spring (Djamali et al., 2008a). Today, the lake is supplied by direct precipitation $\left(\sim 300 \mathrm{~mm} \cdot \mathrm{yr}^{-1}\right)$, inflow from 13 permanent rivers and also from periodic discharge into the lake by seasonal rivers and creeks (Alipour, 2006). According to Kelts and Shahrabi (1986), ancient terraces show evidence of large fluctuations in lake level during Pleistocene. Historical documents and analysis of recent satellite images show fluctuations ranging from 1.0 to $3.5 \mathrm{~m}$, with an estimated lowest lake level during the Little Ice Age ( XIV-XIX centuries; Kelts and Shahrabi, 1986; Alipour, 2006). Nevertheless, 
117 1,271 $\mathrm{m}$ a.s.l. in 2010 , reducing the surface of the lake from $5700 \mathrm{~km}^{2}$ to 4610 and after that to

$1182400 \mathrm{~km}^{2}$ (Fig. 1b), resulting in the salinity increase above $300{\mathrm{~g} . \mathrm{L}^{-1}}^{-}$and dramatic ecologic

119 consequences for the lake catchment area (Alipour 2006; Asem et al., 2014).

120

121

122

123

124

\subsection{Geological setting}

Iran lies in the Alpine-Himalayan orogenic belt. The North-West of the country, where Lake Urmia is located, is a part of the Turkish-Iranian Plateau with an average altitude of around 2000 $\mathrm{m}$ a.s.1. and is situated in the center of the Arabian-Eurasian collision zone. The crustal deformation since the upper Miocene is dominated by N-S shortening and E-W extension (Berberian and Arshani, 1975, Solaymani, 2009). This resulted in faulting, seismic activities and the forming of volcanoes which are the highest mountains on the plateau. As other lakes in the area, Lake Urmia is located in a tectonic depression related to the large zones of faulting. The Tabriz fault system limits this depression to the North-East while the Sahand volcano (3695 m a.s.1.; 3rd highest volcano on the plateau), dominates the east of the lake area. About $100 \mathrm{~km}$ to the west of the lake lies the active Zagros thrust belt. This tectonic activity results in intense seismicity. The archives show that since $600 \mathrm{BC}$, more than 450 big earthquakes happened in the region. Recent and historic data since $858 \mathrm{AD}$ record a high seismic activity in the area of Urmia, especially associated with the Tabriz fault. In this time span, at least 12 major catastrophic earthquakes destroyed the town of Tabriz (Solaymani 2009).

Lake Urmia catchment area is composed of rocks ranging from Precambrian to Quaternary. Volcanic and volcano-sedimentary formations dominate in the east and northeast of the catchment area. Intrusive rocks, as well as metamorphic rocks, are mainly found in the south, west, and northwest (Fig. 1d). Carbonate sedimentary units are mainly found in southern and western parts, and evaporite sedimentary units are present to the northeast of the watershed area. According to Kelts and Shahrabi (1986), Lake Urmia sediments are principally composed of detrital particles of varying grain size (clays-silts-sand-gravel), chemically precipitated aragonite, shrimp fecal pellet sands, thin aragonite crusts, ooids, and evaporites. 


\section{Materials and methods}

144

145

\subsection{Material collection}

During the fieldwork campaigns in 2016 and 2017, seven sediment cores ( $0.6 \mathrm{~m}$ to $14.2 \mathrm{~m}$ long) have been drilled out from recently dried out part of the lake near the city of Urmia. Water sampling and in-situ measurements were performed on the lake and river as well as on groundwater (Fig. 2, Tab. 1). The shortest $0.6 \mathrm{~m}$ long core Golman 4 has been taken manually, directly to the plastic tube and close to the today's lake shoreline, for the retrieval of the lakesediment interface. This provided a sampling of the undisturbed, continuous top sedimentary sequence of the lake. Six other cores have been taken with a mechanic corer and casing of the borehole at a distance from the today's shoreline allowing safe using of the corer. Therefore, all cores have been taken from the recently dried out lake bottom (Fig. 2a). Below the surficial crust, the uppermost sediment was soft sand-rich, and was collected either as compacted (Golman 5 and Golman 6) or incomplete sequence (Golman 3 and Golman 7). The two longest cores, i.e. Golman 3 and Golman 7, were empty in their middle part; too liquid, either sandy or clayish sediment being impossible to be taken out, the solid lower sequence was lightly compacted during coring. When coring reached the depth of $\sim 5 \mathrm{~m}, \mathrm{H}_{2} \mathrm{~S}$ gas began bubbling (Fig. 2b). Corings Golman 3 and Golman 7 were stopped when pressurized water with mud and gas with an intense $\mathrm{H}_{2} \mathrm{~S}$ odor rose up from the boreholes to the sediment surface. Cores Golman 1 and Golman 2 were very incomplete and only small and disturbed fragments of sediment were collected but not analyzed. In-situ parameters such as temperature, $\mathrm{pH}$ and conductivity have been measured on surface water (Lake Urmia and Shahr Chai River at several locations) and on groundwater (rising-up muddy water from coring wells as well as 6 surrounding wells distributed according to a potential flow line). Samples from all water points have been taken for chemical (major anions and cations) and stable isotope analyses $\left({ }^{18} \mathrm{O}_{\text {water }},{ }^{2} \mathrm{H}_{\text {water }}\right)$. During fieldworks, we observed important lake water level changes both in seasonal and annual scale. In May 2016, the lake water level decreased by $\sim 1 \mathrm{~m}$ just due to the end of the winter/spring intense rainfall period 
169 and the increase of the evaporation rate (Fig. 2c). In September of 2017, the water level had

170 lowered so that the lake water sampling sites from 2016 had become dry (Fig. 2d).

171 3.2. Methods

172 On the field temperature, water electric conductivity and $\mathrm{pH}$ of were measured with WTW 3210

173 conductivity meter and $\mathrm{pH}$-meter respectively. Sediment characteristics have been obtained

174 through laboratory analyses as presented below.

175 3.2.1. Measurements of water contents and salinity

176 Water content in sediment was obtained through the difference of weighted humid, immediately

177 taken from fresh core sediment samples and the same samples weighted after drying for three 178 days at $80^{\circ} \mathrm{C}$ in a laboratory oven.

179 The salinity measurements had to take into account the fact that salt is present both in the solution 180 and in the solid part of sediment. Therefore, the total salt content was obtained by washing the 181 salts from the dried out sediments three times with distilled water and weighting the remaining 182 dried fraction. The difference between the mass of dried out sample and the mass of the dried out 183 sample after washing gives the quantity of salt which we normalized by the water content. In the 184 following equation, the numerator corresponds to the quantity of soluble material washed out of 185 the sediment and the denominator to the water content.

$186 S=\frac{W_{\text {Bdry }}-W_{\text {WOdry }}}{W_{B}-W_{\text {Bdry }}}$

187 Where:

$188 W_{B}$, mass of bulk fresh sample

$189 W_{\text {WOdry }}$, mass of washed out and dried sample

$190 W_{B d r y}$, mass of bulk dried sample

191 3.2.2. Grain size, carbonate content and bulk sediment mineralogy 
192 Grain-size distribution measurements of organic matter and carbonate-free sediment were carried 193 out on a Malvern Mastersizer 2000 apparatus. The carbonate content $\left(\mathrm{CaCO}_{3}+\mathrm{MgCO}\right)$ was 194 obtained using a Mélières mono-calcimeter: $100 \mathrm{mg}$ of dried and homogenized bulk sample was 195 reacted with $3 \mathrm{~mL}$ of $1 \mathrm{~N}$ hydrochloric acid $(\mathrm{HCl})$ in a closed vessel and the resulting pressure of $196 \mathrm{CO}_{2}$ gas was measured by a manometer. The calibration was conducted by reacting $100 \mathrm{mg}$ of 197 pure calcium carbonate as standard with $3 \mathrm{~mL}$ of $1 \mathrm{~N} \mathrm{HCl}$, implying a 1 atm pressure read on the 198 manometer. These measurements were done at GEOPS laboratory (University Paris-Saclay, 199 Orsay, France).

200 Identification of mineralogical components was performed by XRD on the whole sediment 201 powder at GEOPS laboratory. The XRD pattern was recorded with an X'Pert Pro PANalytical 202 diffractometer, $\mathrm{Cu}-\mathrm{K} \rightarrow$ source, $2 \Theta$ range $5^{\circ}-80^{\circ}$, 4-h runs and identification phase using 203 PANalytical HighScore software and crystallography open database following the laboratory 204 routine at GEOPS laboratory. Specific carbonates were identified through analyzes during 45 205 minutes with $2 \Theta$ range $24^{\circ}-33^{\circ}$. The semi-quantification of the carbonates was obtained by 206 normalizing the areas of the diffraction peaks with respect to the percentage of areas coming from 207 an equi-mass mixture of carbonates, then setting the ratio of the normalized area of each 208 carbonate to the sum of the standardized areas.

\subsubsection{Magnetic parameters}

210 Low field magnetic susceptibility was measured with a Bartington Instruments MS-2 susceptibility bridge directly on the sediment surface of the half-core. The thermomagnetic behavior of the bulk sediment samples was determined on a horizontal force translation Curie balance. Analyses were performed under normal air atmosphere, in a magnetic field of $0.375 \mathrm{~T}$ and with a linear temperature increase of $10^{\circ} \mathrm{C} \min ^{-1}$. The XRD pattern of the magnetic extracts was recorded with an X'Pert Pro PANalytical diffractometer, $\mathrm{Cu}-\mathrm{K} \rightarrow$ source, 8-h runs and

216 Panalytical Low background substrate, i.e. a 32-mm silicon single crystal substrate for 
217 measurements of small amounts of sample material that require low background intensity. 218 Magnetic susceptibility, XRD and Curie balance experiments were carried out at GEOPS 219 laboratory. Magnetic hysteresis measurements of the bulk sediment samples were performed at room temperature with an alternating gradient magnetometer (AGM 2900 - Micromag) at LSCE laboratory, CNRS/CEA at Gif-sur-Yvette, France. A peak - applied field of $1 \mathrm{~T}$ was used for hysteresis measurements. The values of saturation magnetization (Ms), saturation remanent magnetization (Mrs) and coercive force $(\mathrm{Bc})$ were estimated from the slope corrected hysteresis loop. Parameters Ms and Mrs were mass normalized. Coercivity of remanence (Bcr) was obtained by step-wise application of back-fields to remove the saturation remanence.

Magnetic susceptibility was measured on all sediment cores while other parameters were measured systematically on core Golman 7 and additionally in some other sequences.

\subsubsection{Radiochronology}

Six AMS datings have been done on organic fractions (diffused organic matter and hand-picked charcoal).

Each fraction has been submitted to the standard chemical protocol for AMS analyses for organic remains, i.e. cleaning treatment via successive hydrochloric acid/sodium hydroxide/hydrochloric acid baths respectively, and rinsed with deionized water up to neutral $\mathrm{pH}$. Samples were then gently dried at $60^{\circ} \mathrm{C}$ overnight. $\mathrm{CO}_{2}$ gas was obtained according to the AMS protocol of burning at $860{ }^{\circ} \mathrm{C}$ for $30 \mathrm{~min}$, under vacuum, in presence of a mixing of copper(II)-oxide/copper(III)oxide and silver thread. Then, AMS- ${ }^{14} \mathrm{C}$ targets were obtained by graphitization of the $\mathrm{CO}_{2}$ gas on powdered iron with hydrogen at $650{ }^{\circ} \mathrm{C}$ for $100 \mathrm{~min}$, and graphite compression under analytical plots. Aliquot of the $\mathrm{CO}_{2}$ gas was then used for associated ${ }^{13} \mathrm{C}$ measurement. These were measured on a VG SIRA 10 IRMS (Isotope Ratio Mass Spectrometer) at the GEOPS laboratory. Graphite sources were also prepared at GEOPS laboratory, and counted by the accelerator mass spectrometer at LSCE laboratory (ECHoMICADAS facility, France). 
242 Analytical uncertainties, including laboratory errors, are $\pm 0.1 \%$ for $\delta^{13} \mathrm{C}$ and between 0.5 and 0.8

$243 \mathrm{pMC}$ for ${ }^{14} \mathrm{C}$ activity. All the dates are converted to calendar ages according to the revised

244 calibration program CALIB 7.10 (Reimer et al. 2013, Execute Version 1.10html 2020).

245 4. Results

246

\subsection{Water measurements}

247 Results of in-situ measured electric conductivity (EC), $\mathrm{pH}$ and temperature on surface water and 248 groundwater are presented in the Table. 1. At a first glance, data from both field campaigns (May 2492016 and September 2017) show that lake's basin waters present a wide range of EC values, 250 varying from $0.25 \mathrm{mS} . \mathrm{cm}^{-1}$ for the Shahr Chai River far from the lake, to $227 \mathrm{mS} . \mathrm{cm}^{-1}$ for the coring muds. Considering the flow line of the Shahr Chai River, the conductivity and temperature remain low close to its source above the dam and in the city of Urmia $\left(0.30\right.$ and $0.25 \mathrm{mS}_{\mathrm{cm}} \mathrm{cm}^{-1}$, $\sim 14^{\circ} \mathrm{C}$, respectively) and increase between the city and the river outlet $\left(3.40 \mathrm{mS} . \mathrm{cm}^{-1}\right.$ and $\sim 17^{\circ} \mathrm{C}$ respectively) while $\mathrm{pH}$ shows opposite trend. Groundwater from wells presents temperatures varying between 14.2 and $19.9^{\circ} \mathrm{C}, \mathrm{pH}$ evolving from 6.1 to 8.1 and conductivity comprised between 0.58 and $12.39 \mathrm{mS} . \mathrm{cm}^{-1}$. Lake surface water temperature reaches even $28^{\circ} \mathrm{C}$; its conductivity and $\mathrm{pH}$ are respectively $\sim 200 \mathrm{mS.cm}{ }^{-1}$ and 7.5 to 8.0 , depending of the measurement site. Groundwater (more or less muddy) rising up to the sediment surface in the boreholes, presents very high conductivity and relatively low $\mathrm{pH}$.

Water samples taken upstream from the town of Urmia show EC values in agreement with drinking water standards, either of good quality (until $0.80 \mathrm{mS} . \mathrm{cm}^{-1}$ ) or acceptable (up to 2.50 $\mathrm{mS} . \mathrm{cm}^{-1}$ at a maximum; Drinking Water Directive of European Commission, 2021). About $10 \mathrm{~km}$ downstream from Urmia city and towards the lake, EC values evolve from $3.40 \mathrm{mS}^{-\mathrm{cm}^{-1}}$ to 207.0 $\mathrm{mS} . \mathrm{cm}^{-1}$, indicating an increase in the evaporation rate. Three of the wells used for drinking water until 2016 are now abandoned. Lake Urmia brine's points out a measured conductivity of 207 $\mathrm{mS} . \mathrm{cm}^{-1}$. Such a high conductivity has been also found in waters rising up from coring wells, and 
267 likely representing captive brines they are markers of ancient lake state. In a $\mathrm{pH}$ vs EC diagram 268 (Fig. 3a), two different clusters of conductivity are highlighted and in relation with the two 269 captive brines values. The first (A) displays mean value of $221 \pm 4 \mathrm{mS}^{\mathrm{c}} \mathrm{cm}^{-1}$ and characterizes 270 waters rising steeply from intermediated depths during coring (below 4.5-5 m), while the second 271 one (B), with mean value of $146 \pm 8 \mathrm{mS} \cdot \mathrm{cm}^{-1}$, characterizes highly pressurized water coming

272 from the bottom of core Golman 3. Similar pressurized water was coming from the bottom of the 273 Golman 7 coring tube but unfortunately could not be sampled.

\section{4.2. Sedimentary record}

275 Sediments obtained from cores Golman consist of fine - silty/clayish and sandy deposits with some gravel levels and some sections that contain ooids and fecal pellets of the brine shrimp

277

278 279 280

281

282

283

284 285 Artemia urmiana (Fig. 2e-h). The shortest core Golman 4 (Fig. 2e, Fig. 4a) presents continuous sequence of top $0.60 \mathrm{~m}$ sediment. The cores Golman 3 and Golman 7 are, respectively, 14.20 and $12.50 \mathrm{~m}$ long sequences but present an important gap in the middle due to the liquidity of sandy and clayish/silty sediments (Fig. 4c and d). Sedimentary sequences of both cores display the same pattern although Golman 7 is more complete. Sequences of the cores Golman 5 and Golman 6 (3 and $8 \mathrm{~m}$ long, respectively, Fig. 4b, e), are in good agreement with those for cores Golman 4 and Golman 7. Moreover, the section between 8.00 and $4.20 \mathrm{~m}$ depth of the core Golman 6 completes the gap in the core Golman 7 (Fig. 4f,g), both cores have been collected very close to each other (Fig. 2a).

\subsubsection{Correlations between cores, reconstruction of the composite core and lithology}

The reconstruction of a complete sequence is based on detailed sedimentary description, carbonate contents and magnetic susceptibility, and the correlation, in a reliable and precise way, of characteristic levels between different cores. This composite sequence will allow us to integrate, and therefore to interpret, all the data on a single stratigraphic sequence. 
291 In the uppermost part of the lake sedimentary sequence (i.e. core Golman 4; Fig. 4a), the

292 magnetic susceptibility relatively high in the lower, sandy part of the section, decreases at $\sim 0.20$

$293 \mathrm{~m}$ depth and stays low to the top in fine grained sediments while the carbonate contents present

294 the inverse evolution, i.e. low at the beginning and increasing up to $\sim 0.20 \mathrm{~m}$ depth. Similar

295 pattern and change are recorded in the core Golman 5 at $\sim 1 \mathrm{~m}$ depth (Fig. 4b). Above this change,

296 in both cores, fecal pellets are very abundant. Magnetic susceptibility of the upper sediment in

297 cores Golman 3, 5, 6 and 7, shows varying values with an increase at the depth of $\sim 3 \mathrm{~m}$ that is

298 easily correlated between all cores and is highlighted by a grey band on Fig. 4. This increase

299 corresponds to the presence of blackish sandy sediment rich in organic remains, and to the

300 decrease of the carbonate contents recorded in cores Golman 5 and Golman 7 (Fig. 4b, d). Three

301 different changes of the magnetic susceptibility below this section are indicated by grey lines on

302 Fig. 4. The increased magnetic susceptibility recorded in the lowermost sediments of cores

303 Golman 3 and Golman 7 as well as pressurized water and gas rising from the bottom to the

304 sediment surface there, allow the correlation of both beginnings of cores. The highest value of the

305 susceptibility was recorded at $\sim 1 \mathrm{~m}$ depth in the sandy sediment of the core Golman 3 . This, due

306 to a piece of a broken corkscrew found in this level during sediment sampling, clearly indicates

307 modern age for this sediment (Fig. 4c).

308 Cores Golman 7 and Golman 6 display the complete sequence of the sediment from 12.5 to 1.60

$309 \mathrm{~m}$ depth. The sediment between 12.50 and $12.38 \mathrm{~m}$ depth is sandy (Fig. 2f) and silty. The color of

310 the lowest, sandy $\sim 2 \mathrm{~cm}$ layer is light brown while above, it is black and rich in plant remains

311 (between 12.47-12.44 m) and dark grey. From 12.38 to $4.52 \mathrm{~m}$ depth, the sediment consists of

312 quite soft and grey silt/clay (Fig. $2 \mathrm{~g}$ ), with some fine ( $\sim 1 \mathrm{~mm}$ thick), dark grey sandy laminae.

313 After a clear change at $4.52 \mathrm{~m}$, the upper sediment is more complex with alternation of sands,

314 silts and clays of different colors and some discontinuities. The $4.52-3.73 \mathrm{~m}$ interval presents

315 brownish, coarse silty quite compact sediments $(4.52-4.02 \mathrm{~m})$, clayish/silty grey and brown

316 deposits $(4.02-3.85 \mathrm{~m})$ and dark grey sand $(3.85-3.73 \mathrm{~m})$. Above, between 3.73 and $2.87 \mathrm{~m}$ 
317 depth, the sediment is quite homogeneous, made of grey fine silt and clay that is very rich in 318 shrimp's fecal pellets (Fig. 2h). It begins as a hard $2 \mathrm{~cm}$ thick horizon clearly separated from 319 lower dark grey sand, and becomes quite soft in the middle. The last few centimeters are light 320 grey, quite dry and end sharply at $2.87 \mathrm{~cm}$ depth below the $8 \mathrm{~cm}$ thick black and sandy sediment that is rich in organic remains including plant fragments. Above, the sandy sediment, more or less dark and devoid of fecal pellets, continue until $2.20 \mathrm{~m}$. The upper 2.20-1.60 m sands and silts contain varying concentrations of fecal pellets.

\subsubsection{Radiochronology}

Four ${ }^{14} \mathrm{C}$ AMS datings have been obtained from charcoal and two others, from organic matter (Table. 2). Dating for core Golman 7 present ages of 29.70, 18.34 and 5.52 cal kyr BP at 12.46 $\mathrm{m}, 4.05 \mathrm{~m}$ and $2.80 \mathrm{~m}$ depth respectively. Two additional dating performed on core Golman 5 at 2.66 and $2.34 \mathrm{~m}$ depth, display ages of 4.95 and 4.90 cal kyr BP respectively. These two dated samples represent the same blackish unit with high magnetic susceptibility values as the one in recognized in core Golman 7 at $2.80 \mathrm{~m}$ depth (Fig. 4). Finally, the core Golman 6 sample at 4.40 $\mathrm{m}$ depth indicates 21.20 cal kyr BP. This sample and the $4.05 \mathrm{~m}$ depth sample from the core Golman 7 belong to the same lithological unit (Fig. 4).

Although we were not able yet to determine whether the lake water is submitted to a hard water effect or not, the strong winds existing the region allow the good mixing of the lake water: in such a system, we may consider at a first glance that the lake water total dissolved inorganic carbon (TDIC) is in equilibrium with the atmospheric $\mathrm{CO}_{2}$ (MacDonald et al., 1991; Fontes et al., 1993, 1996; Gibert et al., 1999, 2002a, 2002b; Schneider et al., 2019). However, in order to avoid as much as possible any suspicion of bias in our datings, we thus concentrate on authigenic materials (i) without any link with the carbon lake system such as charcoal, and (ii) with a high C-content for planktonic organic matter and no indication of a detrital origin (mineralogical assemblages). All the ${ }^{14} \mathrm{C}$ datings presented are thus considered as fully reliable. 
342 All these datings are in agreement with the stratigraphy (Fig. 4, Fig. 5). Without any information

343 on the hydrogeochemical balance of the sub-basin of the cored sequences, the interpretation of

344 the ${ }^{14} \mathrm{C}$ datings is only discussed within the framework of the internal consistency of the whole

345 chronology with respect to the lithological sequences.

346 Moreover, the dated samples present associated ${ }^{13} \mathrm{C}$ contents ranging from -26.50 to $-13.50 \%$ vs

347 PDB with a majority of the samples being centered on a value of $-25.2 \%$ vs PDB. This value

348 highlights the predominance of a C3 vegetation over Lake Urmia catchment. The G5-2.34 sample

349 presents a $\boldsymbol{C}^{13} \mathrm{C}$ value corresponding to a $\mathrm{C} 4$ vegetation while sample G7-S2-2.80 exhibits two

350 distinct $\overbrace{}^{13} \mathrm{C}$ values of -13.5 and $-26.5 \%$ vs PDB. This latter is explained by the mixing of two

351 fractions of micro-charcoal, one originating from C3 plants and one from C4 plants, both 352 coexisting in the lake basin (including the lake itself, Decolas-Gros, 1985.) at the time of 353 deposition.

\section{4.2.3. Sediment characteristics}

355 Water contents, salinity and grain size:

356 Water contents in the sediment display values between 12 and 37\% (Fig. 5c), and, as commonly 357 seen, are likely correlated to the grain size; lower water percentages characterising sandy 358 sediments while higher ones correspond to the silty/clayish levels. The calculated salinity 359 indicates relative changes of the total dissolved salts present in interstitial water and sediment. 360 The obtained pattern indicates less salinity in the lower part of the core, as well as at $\sim 3.90 \mathrm{~m}$ and 361 between 3.65 and $2.20 \mathrm{~m}$ depth, and higher but changing salinity elsewhere (Fig. 5d). Mean grain 362 size values vary between $\sim 10$ and $\sim 160 \mu \mathrm{m}$, with a dominant fine silty fraction in the lower part 363 of the core and silty and sandy sediments in its upper part (Fig. 5e). High water contents and low 364 sediment grain sizes, characterize the sequence between 12.38 and $4.52 \mathrm{~m}$ depth, from 4.02 to $3653.85 \mathrm{~m}$ and between 3.73 and $2.87 \mathrm{~m}$ depth. These fine-grained sediments are well correlated 366 with the relatively low water salinity. Sandy/silty sediments that are less humid are present at the 
367 bottom of the sequence at $\sim 12.50 \mathrm{~m}$ depth and in some horizons of its upper $4.52 \mathrm{~m}(4.52-4.02 \mathrm{~m}$, $368 \quad 3.85-3.73 \mathrm{~m}, 2.87-2.40 \mathrm{~m}$, and 2.20-1.60 $\mathrm{m}$ depth).

369 Mineralogy and carbonate contents: XRD mineralogy on bulk sediment has been done on 41 370 samples from cores Golman 3 and Golman 7. Minerals that are identified in all levels are quartz, 371 muscovite, halite and calcite, the two former representing the siliceous detrital fraction. Other 372 carbonates such as aragonite and dolomite were identified in most of the samples. Carbonate 373 contents vary between $\sim 7$ and $\sim 66 \%$ of the total sediment (Fig. $5 f$ ). When existing, aragonite 374 dominates the carbonate fraction and reaches even $65 \%$ while calcite and dolomite have low to 375 very low contents varying between 1 to $12 \%$ for calcite and around $2 \%$ for dolomite (Fig. $5 \mathrm{~g}$ ). 376 Aragonite can be related to the chemical or biochemical precipitation such as calcite, although 377 calcite can be of detrital origin too. Dolomite originates from either chemical precipitation or 378 detrital supply. Microscopic observations and analyses on Lake Urmia sediment by Kelts and 379 Shahrabi (1986) show the predominance of aragonite in the lake sediments. These authors indicate that aragonite is present as mud and at least composes $\sim 80 \%$ of the carbonate as shrimps fecal pellets. In our core, aragonite varies greatly and reaches even $65 \%$ between 3.73 and $2.87 \mathrm{~m}$ depth where shrimp's fecal pellets are particularly abundant.

Magnetic parameters: magnetic susceptibility presents clear changes with alternating sections of low and high values (Fig. 5a). The magnetic hysteresis parameters as Mrs/Ms versus Hcr/Hc for samples from cores Golman 7 and Golman 5 are presented in the Day diagram (Day et al., 1977, Fig. 3b). It shows the distribution of the magnetic particle grain sizes in three clusters: SD magnetic single domain sizes with typical hysteresis loop shape as on Fig. 3d, MD - multidomain, with hysteresis loop as on Fig. 3c, and PSD - pseudo-single-domain intermediated sizes. The PSD and MD sizes are present in the low magnetic susceptibility sediments; generally, the MD are present in sandy, while PSD, in fine silty ones. The thermomagnetic behavior of samples with PSD and MD magnetic minerals during heating shows clearly the Curie temperature at $580^{\circ} \mathrm{C}$ indicating the presence of magnetite $\left(\mathrm{Fe}_{3} \mathrm{O}_{4}\right)$, an iron oxide, in the sediments (Fig. 3e). For 
samples with SD magnetic particles that are mostly correlated with high values of magnetic susceptibility, the Curie balance experiments during heating show a magnetization decrease at $\sim 350^{\circ} \mathrm{C}$. This process is irreversible due to the appearance of new magnetic mineral that is observed during cooling (Fig.3f). Such a behavior is characteristic for greigite $\left(\mathrm{Fe}_{3} \mathrm{~S}_{4}\right)$, an iron sulfide (Jelinowska et al., 1997, 1998, 1999; Strechie et al., 2002; Tudryn et Tucholka, 2004; Tudryn et al., 2013, 2014), whose presence is confirmed through XRD analyses of total sediment and magnetic extracts for the concerned depths (Fig. 3g). Magnetic susceptibility presents a correlated pattern to the mean grain size and anti-correlated ones to the carbonates and water contents with however, some independent peaks at sandy/silty depths of $\sim 12.45 \mathrm{~m}$ and at $\sim 2.80$ $\mathrm{m}$, and larger, silty/clayish section between 8 and $5.5 \mathrm{~m}$ depth (Fig. 5). The considered sandy/silty sediment is black and rich in vegetation remains with numerous pieces of wood while silty/clayish section is grey. In sediments characterized by low magnetic susceptibility values, the magnetic hysteresis parameters and Curie balance experiments allowed the identification of low contents of MD and PSD magnetite (squares and circles on Fig. 3b and circles on Fig.5b) that is of detrital origin while in sections with high magnetic susceptibility, SD greigite appears (black triangles on Fig. $3 \mathrm{~b}$ and Fig. 5b). Greigite is an iron sulfide of early diagenetic origin: it is an intermediated mineral in the authigenesis of the pyrite during the bacterial degradation of the organic matter in the anoxic, sulfate-reducing zone of the sediment or water, where the $\mathrm{S} / \mathrm{Fe}$ ratio is too low to complete the pyritisation process (Berner, 1980; Curtis, 1987). The presence of greigite is surprising in such a saline environment as Lake Urmia, where sulfate ions are abundant in water. Nevertheless, greigite is well known from other hypersaline lakes as Manas in China (Jelinowska et al., 1995, Tudryn et al. 2010), Dead Sea (Frank et al., 2007) and salt marshes (Cutter and Velinsky, 1987). The presence of greigite in such environments is related to the fresh water supply, high organic matter content or, if methane is present in the environment, an anaerobic oxidation of methane by sulfate reduction (either bacterial or not bacterial; e.g. 
419 often associated with black sediment that is rich in plant fragments including pieces of wood (at 420 depths of $\sim 12.45 \mathrm{~m}$ and $\sim 2.80 \mathrm{~m}$ ), it is related to the bacterial degradation of the organic matter in

421 the anoxic, sulfate-reducing zone rather than to methane oxidation.

\section{5. Discussion}

423 As indicated by all our proxies and during all the time covering the sedimentary sequence, the

424 detrital minerals such as quartz and muscovite have been supplied to the lake and evaporitic 425 conditions, with saline waters and precipitation of halite, were prevailing in the Lake Urmia. The 426 electric conductivity of two-captured brines at different depths during coring highlights changes 427 of its salinity in the past.

428 The sequence starts with sandy deposits indicating either a high-energy transport related to the 429 fluvial activity of River Shahr Chai or a low water level at the place of coring. The light brown 430 color of the sand and the presence of detrital magnetite (that is MD and in low contents) highlight 431 well oxygenated conditions during the sedimentation. In these deposits, pressurized gas and brine are captured. The brine shows lower electric conductivity than today's lake waters and thus, less 433 water salinity. A few centimeters above the bottom of the core, at $\sim 30$ cal kyr BP $(12.46 \mathrm{~cm}$ 434 depth), the deposits become black, silty, with some calcite and dolomite but without aragonite. 435 They are rich in authigenic greigite and plant remains that, according to $\rightarrow^{13} \mathrm{C}$ (Table 2), are 436 identified as C3 plants. The former iron sulfide indicates the anoxic and sulfate reducing 437 conditions within the sediment. The high content of organic material here could reflect an 438 increased input of organic detritus through the river, nevertheless the decreased grain size of the 439 sediment and its bad oxygenation suggest the development of a salt marsh with high biological 440 productivity rather than a high river activity. Such a start of the sedimentary sequence reflects 441 quite low lake water level, without lacustrine or very shallow condition in the coring area (Fig. 442 5). The above $\sim 8 \mathrm{~m}$ thick sequence between 12.38 to $4.52 \mathrm{~m}$ depth is quite homogeneous, grey 443 and with high water content. The fine-grained sediment indicates that it was deposited in low 
$4452-3 \%$ of carbonates, either calcite or dolomite, can be of detrital origin according to the 446 distribution of carbonate rocks in the River Shahr Chai catchment area (Fig. 1d). Nevertheless, 447 most of the carbonates are authigenic or bio-mediated as evidenced by the dominance of 448 aragonite mud in the carbonate fraction. According to Kelts and Shahrabi (1986), precipitation of aragonite rather than calcite is a function of the high $\mathrm{Mg} / \mathrm{Ca}$ molar ratio. Relatively low porewater salinity values suggest less saline conditions than in the upper part of the sediment. All parameters provide a coherent indication of higher water level than in the beginning of the sequence, and high enough to show clearly lacustrine conditions at the coring site. The magnetic fraction of this sediment is dominated by detrital, PSD magnetite in its lower part until $\sim 8 \mathrm{~m}$ depth, and by greigite above. Greigite indicates early diagenetic, sulfate reducing processes in anoxic sediment and possibly bad ventilation of the bottom water, in good agreement with high lake level. The presence of magnetite could be interpreted as indicating the good ventilation of the basin during its deposition (between 12.38 and $8.00 \mathrm{~m}$ ), as at the beginning of the sequence at $12.50 \mathrm{~m}$ depth where light brown sand with MD magnetite is present and the PSD magnetite here could reflect the different source of the detrital material. Nevertheless, quite homogeneous conditions recorded between $12.38 \mathrm{~m}$ and $4.52 \mathrm{~m}$, grey color of the sediment and greigite present above 8.00 m (Fig. 2g, Fig. 5) suggest rather anoxic early diagenetic conditions in the magnetite bearing sediments. These conditions without sulfate reduction allowing the iron sulfides precipitation, could favor bacterial reduction of iron oxydes (Curtis, 1987) that resulted in the decrease of their grain size from MD to PSD without their complete dissolution.

These data indicate thus Lake's Urmia low stand at $~ 30$ cal kyr BP. Afterwards the lake level increased and stayed high, probably the highest recorded since that time until today. According to the ${ }^{14} \mathrm{C}$ dating, it finished before 21.20 cal kyr BP (Fig. 5). Djamali et al. (2008a) proposed a high lake water level during the last glacial period while Stevens et al. (2012) indicated a clearly arid climate at Urmia at that time associated to a low lake level and no establishment of a perennial saline lake until $\sim 14 \mathrm{kyr}$. A high stand during the considered part of the glacial period is reported 
471 in the region from other lakes such as Lake Zeribar (Wasylikowa et al., 2006) and Lake Van

472 (Kuzucuoglu et al., 2010).

473 The pattern of all parameters displays several changes in the upper part of the sequence and 474 discontinuities are observed (Fig. 5). It starts, between 4.52 and $4.05 \mathrm{~m}$ depth, with water content 475 decreased, brown sandy/silty low-carbonated sediments that contain MD magnetite, and 476 relatively high salinity probably highlighting a low lake level and well oxygenated environment. 477 According to ${ }^{14} \mathrm{C}$ dating, this low lake stand is recorded between 21.2 and 18.3 cal kyr BP and 478 corresponds to the Last Glacial Maximum (LGM). After that, short-time lacustrine conditions 479 indicated by fine sediment grain sizes, decreased water salinity and increased carbonate contents 480 including aragonite mud (up to $20 \%$ ) were identified between $4.02-3.85 \mathrm{~m}$ depth before a 481 lowering between the depths of $3.85-3.73 \mathrm{~m}$ marked by increased sediment grain sizes and 482 water salinity, and decreased carbonate contents without aragonite. The presence of MD 483 magnetite indicates well oxygenated environment. The re-establishment of clear lacustrine 484 conditions between 3.73 and $2.87 \mathrm{~m}$ depth were recorded by fine-grained sediments, carbonaterich fraction with very high contents of aragonite and abundance of shrimp fecal pellets (Fig. $2 \mathrm{~h}$ ). The presence of some gregite and PSD magnetite, suggest bad ventilation of the bottom water. 487 The beginning and end of this section are marked by sharp change in the lithology, grain size, 488 magnetic susceptibility, carbonate contents and mineralogy. Its lower limit highlighted by the $\sim 2$ 489 $\mathrm{cm}$ thick dried grey sediment, as well as its upper part clearly indicate drying up, and both limits suggest discontinuities in the sedimentation. Above $2.87 \mathrm{~m}$ and until $\sim 2.2 \mathrm{~m}$ depth, dark sandy and silty sediment with low carbonate contents but without aragonite was deposited. Between 2.87 and $2.77 \mathrm{~m}$ depth, it is black and particularly rich in organic remains and greigite. According to the radiocarbon data of this black sediment, this episode started at $\sim 5.5$ cal kyr BP and lasted until at least $\sim 4.9$ cal kyr BP. This sediment suggests similar lake low stand to that recorded at the beginning of the sequence i.e. at $\sim 30$ cal kyr BP, without lacustrine or very shallow condition 
\%o and of $-13.5,-14.50 \%$ vs PDB (Table 2), the first originating from C3 plants and the second

498 from C4 plants, both coexisting on the watershed at the time of deposition. We observed that the $499 \mathrm{C} 4$ vegetation episode that seems to have lasted at least 600 years, between 5.5 and 4.9 cal kyr 500 BP likely indicates a warmer and drier episode. The latest recorded sandy sediment rich in shrimp 501 fecal pellets (2.20-1.60 m), reflects a lacustrine episode with River's Shahr Chai high energy 502 transport at the place of the coring site. Today, the downstream electric conductivity 503 measurements of River Shahr Chai and of lake water indicate an increase in the evaporation rate 504 with its very high values for the lake. These results are in good agreement with our first 505 hydrogeochemical results on the water samples (E. Gibert-Brunet, pers. comm., Kong et al., 506 2019). According to these results, including rivers and surrounding wells, the lake is fed not only 507 by direct precipitations and inflow of rivers, but also by groundwater discharge. This present-day 508 discharge has very likely evolved over time in relation with the lake level and could have been 509 more important during the first phases of lake level drop.

510 According to ${ }^{14} \mathrm{C}$ dates, Lake Urmia evolution from the LGM until today was characterized by 511 lake level fluctuations with three high and three low stands recorded at the coring site (Fig. 5). 512 Kelts and Shahrabi (1986) identified, in the $\sim 4 \mathrm{~m}$ thick sedimentary sequence from South Lake 513 Urmia basin, three lacustrine high stands that they named "Aragonite-Pellet-Mud" (APM) and 514 two low ones stamped "Playa-Lake-Mud" (PL). Authors highlighted the lack of readily dateable 515 material in their study, but proposed $\sim 9-7.5 \mathrm{kyr}$ BP for the lake high stand APM-2. This Early 516 Holocene timing is in good agreement with the relatively long-term lacustrine conditions we 517 recorded before $\sim 5.5$ cal kyr BP. Previous study by Stevens and coauthors (2012) in the eastern 518 part of Lake Urmia described dry condition during the Late Pleistocene with a short-term 519 lacustrine episode at $\sim 14 \mathrm{kyr}$, drying out probably in phase with the Younger Dryas and no re520 establishment of lacustrine conditions until 10 kyr. Holocene reconstructions by Sharifi (2018) suggested wet Early Holocene and frequent dry episodes during Mid to Late Holocene. 
522 Contrary to the lacustrine records from Zagros Mountains (lakes Zeribar, Mirabad, Dasht-e 523 Arjan) that indicate dry conditions and low lake levels during the Early Holocene (Stevens et al., 524 2006; Wasylikowa et al., 2006; Aubert et al., 2019), clearly lacustrine conditions dominated in 525 Lake Urmia at that time. Such wetter conditions than those prevailing in the Zagros area, as well 526 as changing ones during the Late Holocene, are in good agreement with data from Lake's Neor 527 area, located in the NW Iran (Sharifi et al., 2015; Aubert et al., 2017).

528 Transition from Early to Late Holocene in Lake Urmia, was marked by a low lake level and thus 529 dry conditions between $\sim 5.5$ and $\sim 4.9$ cal kyr BP. Such a dry event was identified during broadly 530 the same time in Zagros Mountains (Stevens et al., 2006) and in Anatolia (Fontugne et al., 1999). 531 It is probably linked to the drought event recorded at $5.2 \mathrm{kyr}$ BP that was evidenced in the Soreq 532 speleothem record (Bar-Matthews et al. 1997) and in many others sites (see in Staubwasser et 533 Weiss, 2006). Jones and co-authors (2013) pointed out the scarcity of information and the 534 problems with identification and timespan of this event in Iran; the complex interplay between 535 natural conditions and humans during much of the Holocene in Iran makes this information 536 difficult to obtain.

\section{Conclusion}

538 The sediment cores collected from the SW part of Lake Urmia close to the city of Urmia 539 represent a Late Pleistocene and Holocene record of the paleohydrological evolution of the lake.

540 Our proxies indicate that during the whole deposition period of the sedimentary sequence, the 541 detrital minerals, such as quartz and muscovite, have been supplied to the lake. Aragonite (if 542 present in the sediment) dominated the carbonate fraction and evaporitic conditions with saline 543 waters and precipitation of halite, were prevailing in the lake.

544 Our established timescale is based on 6 reliable ${ }^{14} \mathrm{C}$ datings that give chronological anchors for 545 the presented data. A low stand of the lake was identified at about 230 cal kyr BP (and even 546 drying out at the coring site) and followed by a water level rise leading to establishment of 547 lacustrine conditions, with probably the highest water level from that time until today. According 
548 to the ${ }^{14} \mathrm{C}$ dating, the water level decreased prior to the LGM. Lake evolution from the LGM until

549 today was characterized by several changes of the water level with clearly lacustrine conditions

550 and lake low stands. Between $\sim 5.5$ and 4.9 cal kyr BP, the lake experienced low stand and even

551 drying out at the coring site. Just before this, during the Early Holocene, relatively long-term

552 lacustrine conditions were established.

553 Sediments from two dry events at the coring site recorded at $\sim 30$ and at $5.5-4.9$ cal kyr BP are 554 characterized by high contents of authigenic greigite associated to the organic matter rich 555 environment. Elsewhere, in sandy sediments, low contents of MD detrital magnetite are present 556 while in fine grained ones, PSD magnetite or greigite dominate. These changes of the magnetic 557 mineralogy reflect differences in the oxygenation state of lake sediment and water.

558 Our work has allowed presenting a Late Pleistocene and Holocene record of the 559 paleohydrological evolution of Lake Urmia based on the valuable material collected, including 560 sediments and water. Those first results open a wide possibility for further analysis and 561 crosschecking, associated to the strengthening of the ${ }^{14} \mathrm{C}$ chronology to establish a high temporal 562 resolution of the lake evolution. The pluridisciplinary study of Lake Urmia basin will enable to 563 extend the discussion on environmental changes to the regional scale.

\section{7. Acknowledgement}

565 This work was supported by the French-Iranian project Gundishapur, the Center for International 566 Scientific Studies and Collaboration (CISSC), TelluS Program of CNRS/INSU and China 567 Scholarship Council (CSC) for one of the coauthors PhD fellowship. We thank Kuadio A., 568 Yilmaz N., Chanon C., Coulibaly S., Belarb S., Convard de Prolles A., Lezeau G. and 569 Randrianarivélo C., students from Paris Sud University who contributed to this work during their 570 Licence and Master traineeship.

\section{8. References}


572 Ahmady-Birgani, H., Ravan, P., Schlosser, J. S., Cuevas-Robles, A., AzadiAghdam, M., \& 573 Sorooshian, A., 2020. On the chemical nature of wet deposition over a major desiccated lake:

574 Case study for Lake Urmia basin. Atmospheric Research, 234, 104762.

575 Ahmady-Birgani H., Agahi_E., Ahmadi S.J., Efranian M., 2018. Sediment source fingerprinting 576 of the Lake Urmia sand dunes, Scientific Reports, DOI:10.1038/s41598-017-18027-0.

577 Alipour S., 2006, Hydrogeochemistry of seasonal variation of Urmia Salt Lake, Iran, Saline 578 Systems 2006. 2:9, doi:10.1186/1746-1448-2-9.

579 Asem A., Eimanifar A., Djamali M., De los Rios P., Wink M., 2014. Biodiversity of the 580 Hypersaline Urmia Lake National Park (NW Iran). Diversity 6:102-132.

581 Aubert C., Brisset B., Djamali M., Sharifi A., Ponel Ph., Gambin B., Akbari Azirani T., Guibal 582 F., Lahijani H., Naderi-Beni A., de Beaulieu J.-L., Pourmand A., Andrieu-Ponel V., Thiéry A., 583 Gandouin E., 2017. Late Glacial and Early Holocene hydroclimate variability in northwest Iran 584 (Talesh Mountains) inferred from chironomid and pollen analysis. Journal of Paleolimnology, 585 Springer Verlag, 2017, 58 (2), pp.151-167.

586 Aubert C., Djamali M., Jones M., Lahijani H., Marriner N., Naderi-Beni A., Sharifi A., Ponel Ph., 587 Gandouin G., 2019. A major hydrobiological change in Dasht-e Arjan Wetland (southwestern 588 Iran) during the Late Glacial - Early Holocene transition revealed by subfossil chironomids. 589 Canadian journal of earth sciences, National Research Council Canada, 56 (8), pp.848-856.

590 Avrahamov N., Antler G., Yechieli Y., Gavrieli I., Loye B., Saxton M., Turchyn A.V., Sivan O., 591 2014. Anaerobic oxidation of methane by sulfate in hypersaline groundwater of the Dead Sea 592 aquifer, Geobiology, 12, 511-528.

593 Azarbaidjan Regional Mining Cooperation, 1995. Report on the Hydrochemistry of Urmia Lake.

594 Bar-Matthews M., Ayalon A., Kaufman A., 1997. Late quaternary paleoclimate in the eastern 595 Mediterranean region from stable isotope analysis of speleothems at Soreq Cave, Israel. 596 Quaternary Research 47, 155-168. 
597 Berner R.A., 1980. Early diagenesis: a Theoretical Approach, Princeton University Press, 598 Princeton, 1980.

599 Bottema S., 1986. A late Quaternary pollen diagram from lake Urmia (Northwestern Iran), Rev. 600 Palaeobot. and Palynol., 47:241-261.

601 Curtis C., 1987. Mineralogical consequences of organic matter degradation in sediments: 602 inorganic/organic diagenesis. In: Legget JK, Zuffa GG (eds) Marine clastic sedimentology. 603 Graham and Trotman, London, pp 108-123.

604 Cutter G.A. and Velinsky D.J., 1987. Temporal variation of sedimentary sulfur in a Delaware salt 605 marsh, Marine Chemistry, 23, 311-327.

606 Day R., Fuller M., Schmidt V.A., 1977. Hysteresis properties of titanomagnetites: grain-size and 607 compositional dependence. Phys Earth Planet Inter 13:260-267.

608 Decolas-Gros C., 1985. La fixation du carbone inorganique par le phytoplancton marin : données 609 bibliographiques sur les carboxylases et le rapport isotopique 13C/12C. VIE MILIEU, 1985, 35 610 (1): 33-41.

611 Djamali M., de Beaulieu J.-L., Shah-Hosseini M., Andrieu-Ponel V., Ponel PH., Amini A., 612 Akhani H., Leroy S.A.G., Stevens L., Lahijani H., Brewer S., 2008a. A late Pleistocene long 613 pollen record from Lake Urmia, NW Iran, Quaternary Research, 69, 413-420.

614 Djamali, M. Kürschner, H. Akhani, H. de Beaulieu, J.L. Amini, A. Andrieu-Ponel, V. Ponel, P., 615 Stevens, L., 2008b. Palaeoecological significance of the spores of the liverwort Riella 616 (Riellaceae) in a late Pleistocene long pollen record from the hypersaline Lake Urmia, NWIran. 617 Review of Palaeobotany and Palynology, 152, 66-73.

618 Djamali M., Ponel Ph., Delille T., Thiéry A., Asem A., Andrieu-Ponel V., de Beaulieu J., 619 Lahijani H., Shah-Hosseini M., Amini A., Stevens L., 2010. A 200,000-year record of Artemia 620 remains (Crustacea, Anostraca) in Lake Urmia, NW Iran. Int. J. Aquat. Sci.,1, 14-18. 
621 Fontes J.Ch., Mélières F., Gibert E., Liu Qing \& Gasse F., 1993. Stable isotope and radiocarbon 622 balances of two tibetan lakes (Sumxi Co and Longmu Co) from 13,000 yr B.P., Quaternary 623 Science Reviews, 12, 875-887.

624 Fontes J.Ch., Gasse F. \& Gibert E., 1996. Holocene environmental changes in Bangong basin 625 (western Tibet). Part 1 : modern setting, mineralogy, stable isotope of carbonates and radiometric 626 chronology, Palaeoclim., Palaeogeog., Palaeoecol., 120: 25-47.

627 Fontugne M., Kuzucuoglu C., Karabiyikoglu M., Hatté C., Pastre J.-F., 1999. From Pleniglacial 628 to Holocene: a ${ }^{14} \mathrm{C}$ chronostratigraphy ofenvironmental changes in the Konya Plain, Turkey, 629 Quaternary Science Reviews 18, 573-59.

630 Frank U., Nowaczyk N.R., Negendank J.F.W., 2007. Rock magnetism of greigite bearing 631 sediments from the Dead Sea,Israel, Geophys. J. Int., 168, 921-934.

632 Gibert E., Travi Y., Massault M., Chernet T., Barbecot F., Laggoun-Defarge F., 1999. 633 Comparison between carbonate and organic AMS ${ }^{14} \mathrm{C}$ ages in Lake Abiyata sediments (Ethiopia): 634 hydrochemistry and palaeoenvironmental implications, Radiocarbon, 41(3): 251-266.

635 Gibert E., Bergonzini L., Massault M., Williamson D., 2002a. AMS- ${ }^{14} \mathrm{C}$ chronology of 636 continuous deposits from a crater lake (Lake Massoko, Tanzania): modern water balance and 637 environmental implications, Palaeoclim., Palaeogeog., Palaeoecol., 187:307-322.

638 Gibert E., Travi Y., Massault M., Tiercelin J.-J., Chernet T., 2002b. AMS- ${ }^{14} \mathrm{C}$ chronology of a 639 lacustrine sequence from Lake Langano (Ethiopia): correction and validation steps in relation 640 with volcanism influence, and lake water and carbon balances, Radiocarbon, 44:75-92.

641 Jalili S., Hamidi S.A., Ghanba R.N., 2016. Climate variability and anthropogenic effects on Lake 642 Urmia water levelfluctuations, northwestern Iran, Hydrological Sciences Journal DOI: $643 \quad 10.1080 / 02626667.2015 .1036757$.

644 Jelinowska A., Tucholka P., Gasse F. and Fontes J.Ch., 1995. Mineral magnetic record of 645 environment in Late Pleistocene and Holocene sediments, Lake Manas, Xinjiang, China, 646 Geophys. Res. Lett., 8, 953-956. 
647 Jelinowska A., Tucholka P. and Więckowski K., 1997, Magnetic properties of sediments in a 648 Polish lake: Evidence of a relation between rock-magnetic properties and environmetal changes 649 in Late Pleistocene and Holocene sediments, Geophys. J. Int., 129, 727-736.

650 Jelinowska A., P. Tucholka, F. Guichard, I. Lefèvre, D. Badaut-Trauth, F. Chalié, F. Gasse, N. 651 Tribovillard and A. Desprairies, 1998. Mineral magnetic study of Late Quaternary South Caspian 652 Sea sediments: palaeoenvironmental implications, Geophys.J.Int., 133, 499-509.

653 Jelinowska A., Tucholka P. and Badau-Trauth D., 1999. Magnetic mineral variations of South 654 Caspian Sea sediments at laminae scale. Phys. Chem. Earth, 24, 9, 823-828.

655 Jones M., Djamali M., Stevens L., Heyvaert V., Askari H., Noorollahi D., Weeks L., 2013. Mid656 Holocene environmental and climatic change in Iran, In book: Ancient Iran and its neighbours: 657 Local developments and long-range interactions in the 4th Millennium BC., Edition: British 658 Institute for Persian Studies Series, Chapter: 1, Publisher: Oxbow books, Editors: Petrie C.A.

659 Kelts K. and Shahrabi M., 1986. Holocene sedimentology of hypersaline lake Urmia, NW Iran, 660 Palaeogeogr., Palaeoclim.,Palaeoecol., 54,105-130.

661 Kong T., Tudryn A., Gibert-Brunet E., Motavalli-Anbaran S-H., Tucholka P., Lankarani M., 662 Ahmady-Birgani H., Noret A., Massault M., Miska S., Late Quaternary climate and environment 663 reconstruction of Lake Urmia basin (Iran), Inqua Congress, Dublin 25-31 july 2019, Dublin, 664 Ireland.

665 Kuzucuoglu C., Christol A., Mouralis D., Dog A.F., Akköprü E., Fort M., Brunstein D., Zorer 666 H., Fontugne M., Karabiyikog M., Scaillet S., Reyss J.L., Guillou H., 2010. Formation of the 667 Upper Pleistocene terraces of Lake Van (Turkey), Journal of Quaternary Science, 25(7) 11246681137.

669 MacDonald G.M., Beukens R. P., Kieser W. E., 1991. Radiocarbon Dating of Limnic Sediments: 670 A Comparative Analysis and Discussion, Ecology, 72, 3, 1150-1155. 
671 Neretin L., Böttcher M.L., Jorgensen B.B., Volkov I.I., Lüschen H., Hilgenfeldt K., 2004.

672 Pyritization processes and greigite formation in the advancing sulfidization front in the upper

673 Pleistocene sediments of the Black Sea, Geochimica et Cosmochimica Acta, 68, 9, 2081-2093.

674 Pengra B., 2012. The drying of Iran's lake Urmia and its environmental consequences, UNEP

675 Global Environment Alert Service (GEAS).

676 Reimer PJ, Bard E, Bayliss A, Beck JW, Blackwell PG, Bronk Ramsey C, Buck CE, Cheng H,

677 Edwards RL, Friedrich M, Grootes PM, Guilderson TP, Haflidason H, Hajdas I, Hatté C, Heaton 678 TJ, Hogg AG, Hughen KA, Kaiser KF, Kromer B, Manning SW, Niu M, Reimer RW, Richards 679 DA, Scott EM, Southon JR, Turney CSM, van der Plicht J., 2013. IntCal13 and MARINE13 680 radiocarbon age calibration curves 0-50000 years cal BP. Radiocarbon 55(4). DOI: 681 10.2458/azu_js_rc.55.16947.

682 Schneider L., Pain C.F., Haberle S., Blong R., Alloway B.V., Fallon S.J., Hope G., Zawadzki A., 683 Heijnis H., 2019. Evaluating the Radiocarbon Reservoir Effect in Lake Kutubu, Papua New 684 Guinea, Radiocarbon, 61, 1, 287-308.

685 Shah-Hosseini M., (2003). Sedimentology of hypersaline Lake Urmia in central part of Shahid 686 Kalantari Highway with special reference to their origin, M.Sc. Thesis, Department of Geology, 687 University of Teheran, 98p.

688 Sharifi A., Pourmand A., Canuel E.A., Ferer-Tyler E., Peterson L.C., Aichner B., Feakins S.J., 689 Daryaee T., Djamali M., Beni A.N., Lahijani H.A.K., Swart P.K., 2015. Abrupt climate 690 variability since the last deglaciation based on a high-resolution, multi-proxy peat record from 691 NW Iran: The hand that rocked the Cradle of Civilization?, Quaternary Science Reviews, 123, $692 \quad 215-230$.

693 Sharifi A., Shah-Hosseini, M., Pourmand, A., Esfahaninejad, M., Haeri-Ardakani, O., 2018. The 694 Vanishing of Urmia Lake: A Geolimnological Perspective on the Hydrological Imbalance of the 695 World's Second Largest Hypersaline Lake, DOI: 10.1007/698_2018_359, The Handbook of 696 Environmental Chemistry, Springer, Berlin, Heidelberg. 
697 Sharifi A., 2018. The Urmia Lake Environmental Crisis Man vs. Climate, The 3rd International 698 Geosciences Congress of Iran, 26/02/2018, Tehran.

699 Solaymani S., 2009. Evaluation de l'aléa sismique pour les villes de Téhéran, Tabriz et Zandjan 700 dans le NW de l'Iran. Approche morphotectonique et paléosismologique. Tectonique. Université 701 Montpellier 2 Sciences et Techniques du Languedoc, 2009.

702 Staubwasser M., Weiss H., 2006. Holocene climate and cultural evolution in late prehistoric-early 703 historic West Asia, Quaternary Research, 66, 372-387.

704 Stevens L.R., Ito E., Schwalb A., Wright Jr.H.E., 2006. Timing of atmospheric precipitation in 705 the Zagros Mountains inferred from a multi-proxy record from Lake Mirabad, Iran, Quaternary 706 research, 66, 494-500.

707 Stevens L., Djamali M., Andrieu-Ponel V., de Beaulieu J., 2012. Hydroclimatic variations over 708 the last two climatic cycles at Lake Urmia, Iran. J. of Paleolimnology 47, 645-660.

709 Strechie C., André F., Jelinowska A., Tucholka P., Guichard F., Lericolais G., and Panin N., 710 2002. Magnetic mineral as indicators of major environmental change in Holocene Black sea 711 sediments: preliminary results, Phys.Chem. Earth, 27, 1363-1370.

712 Talebi T. Ramezani E., Djamali M., Lahijani H.A.K., Naqinezhad A., Alizadeh K., Andrieu713 Ponel V., 2015. The Late-Holocene climate change, vegetation dynamics, lake-level changes and 714 anthropogenic impacts in the Lake Urmia region, NW Iran, Quaternary International, 715 http://dx.doi.org/10.1016/j.quaint.2015.11.070.

716 Tudryn A. and Tucholka P., 2004. Magnetic monitoring of thermal alteration for natural pyrite 717 and greigite, Acta Geoph. Polon. 52 (4), 509-520.

718 Tudryn A., Tucholka P., Gibert E., Gasse F., Wie K., 2010. A late Pleistocene and Holocene 719 mineral magnetic record from sediments of Lake Aibi, Dzungaria Basin, NW China, J. of 720 Paleolimnology, 44,1, 109-121.

721 Tudryn A., Chalié F., Lavrushin Yu.A., Antipov M.P., Spiridonova E.A., Lavrushin V., Tucholka P., Leroy S.A.G., 2013. Late Quaternary Caspian Sea environment: Late Khazarian and Early 
723 Khvalynian transgressions from the lower reaches of the Volga River, Quaternary International, 724 292: 193-204.

725 Tudryn A., Giannesini P.J., Guichard F., Badaut-Trauth D., Tucholka P., Boomer I., 2014. The 726 role of iron minerals in laminae formation in Late Pleistocene sediments of the Caspian Sea, 727 Quaternary International, 345, 68-76.

728 Wasylikowa K., Witkowski A., Walanus A., Hutorowicz A., Alexandrowich S.W., Langner J.J., 729 2006. Palaeolimnology of Lake Zeribar, Iran, and its climatic implications, Quaternary Research, $73066,477-493$.

731 
734 Fig. 1. Lake Urmia: a) location of the lake, b) lake in 1999 on the left and in 2019 on the right

735 (after Ahmady-Birgani et al., 2020), c) lake's catchment area, hydrography and dams (after

736 Sharifi et al. et al., 2018), red circle indicates coring area, d) simplified geological map of Lake

737 Urmia catchment area (after Sharifi et al., 2018, completed with information from Geological

738 Map of Iran, Sheet No 1 North-West Iran).

740 Fig. 2. Study area: a) location of coring - red circle (Golman coring sites are labeled as G and numbers from G1 to G7), surface- and groundwater sampling - yellow circles and line, Google Earth map (geographic coordinates for all sites are indicated on Tab. 1), b) upper picture - gas and under-pressure mud rising up along the borehole Golman 2 after coring in May 2016, lower pictures - crystallization of muddy salt on the borehole surface, September 2017, c) lake water sampling site at the foot of the east-west dike-type highway in May 2016; arrows indicate two salty lines that highlight water level change in spring 2016, d) lake water sampling site close to the coring Golman 4: above - May 2016, below - September 2017, e) sediment cores Golman 4 and Golman 7 obtained from recently dried out part of the lake, optical microphotograph from core Golman 7 for: f) sand at $12.49 \mathrm{~m}$ depth, g) fine silty, carbonate rich sediment at $10.66 \mathrm{~m}$ depth, h) fecal pellet rich sediment at $3.62 \mathrm{~m}$ depth.

Fig. 3. Parameters measured on water (in-situ measurements) and on sediments : a) electric conductivity versus $\mathrm{pH}$ for water samples from Lake Urmia, River Shahr Chai, wells between Urmia City and the lake border, coring wells, A - captive brine rising-up from intermediated depth (below 4.5-5m), B - captive brine rising-up from the bottom of the core, b) classification of magnetic minerals in terms of magnetization and coercivity ratios after Day et al. (1977); sediments from cores Golman 5 and Golman 7: black triangles - SD magnetic grain sizes, circles 
758 - PSD-like and squares - MD magnetic grain, typical magnetic hysteresis loop of bulk sediment

759 samples with c) MD magnetic grain sizes and d) SD magnetic grain sizes, typical

760 thermomagnetic curve of bulk sediment samples with e) magnetite and f) greigite, g) X-ray

761 diffraction pattern obtained for magnetic extract from core Golman 5 at $2.50 \mathrm{~m}$ depth with mean

762 identified minerals: greigite (Gr), which is highlighted by vertical blue lines, albite (Al), calcite

$763(\mathrm{Ca})$, chlorite $(\mathrm{Ch})$, muscovite $(\mathrm{Mu})$, pyrite $(\mathrm{Py})$, quartz $(\mathrm{Qu})$.

765 Fig. 4.Down-core variation in magnetic susceptibility (black line) and carbonate contents (blue 766 line) for cores: a) Golman 4, b) Golman 5, c) Golman 3, d) Golman 7 and e) Golman 6. Depth 767 scale for core Golman 4 is different from common scale for others cores. Lithological log is 768 presented for core Golman $4 .{ }^{14} \mathrm{C}$ dating for cores Golman 5 (G5), Golman 6 (G6) and Golman 7 769 (G7) are indicated on the common depth scale and as red arrows on corresponding cores. Grey 770 band that shows increased magnetic susceptibility through cores, and grey solid and dashed lines 771 indicate correlations between different cores. Sequences compressed during coring are presented 772 after linear decompression.

774 Fig. 5 Down-core variation in lithology and in a) magnetic susceptibility, b) magnetic mineralogy with $\mathrm{M}$ for magnetite (circle) and $\mathrm{G}$ for greigite (black triangle), c) water contents in the sediment, d) relative salinity on wet sediment samples, e) mean sediment grain size, f) carbonate contents, g) specific carbonate contents. ${ }^{14} \mathrm{C}$ cal BP dates are presented on the left of the depth scale. Lithology, a), b), c), e) and f) present composite data from cores Golman 6 and 7 while d)

779 and g) present data from core Golman 7. 
782 Tab. 1. Location of sampling sites, both water and sediment in the vicinity of Urmia City, and the 783 results of in situ measurements of $\mathrm{pH}$, temperature and electric conductivity. Measurements of 784 surface water, groundwater from wells and groundwater rising-up from coring well Golman 5, 785 have been done in May 2016 or in September 2017. Measurements of groundwater rising-up 786 from coring wells Golman 1, Golman 2 and Golman 3, have been done in May 2016 and in 787 September 2017.

788

789 Tab. $2{ }^{14} \mathrm{C}$ AMS and $\overbrace{}^{13} \mathrm{C}$ data for cores Golman 6 (G6), Golman 7 (G7) and Golman 5 (G5).

790 The calibrated ages are the mean ages.

791

792

793

794

795

796

797

798

799

800

801

802

803

804

805

806

807 


\begin{tabular}{|c|c|c|c|c|c|c|c|c|}
\hline & Site name & comment on sampling & latitude & longitude & $\begin{array}{c}\text { altitude } \\
\mathrm{m} \text { asl } \pm 1 \mathrm{~m}\end{array}$ & $\mathrm{pH}$ & $\begin{array}{l}\text { temp. } \\
{ }^{\circ} \mathrm{C}\end{array}$ & $\begin{array}{l}\text { conduct. } \\
\mathrm{mS} . \mathrm{cm}^{-1}\end{array}$ \\
\hline river & BARDESOOR & above dam, near Silvana City, 09/2017 & $\begin{array}{c}37^{\circ} 26^{\prime} 14.592 \\
"\end{array}$ & $44^{\circ} 49^{\prime 2} 26.92^{\prime \prime}$ & 1606 & 8.38 & 13.8 & 0.299 \\
\hline \multirow[t]{2}{*}{ SHAHR CHAI } & SHAH 1 & Urmia City, 05/2016 & $37^{\circ} 31^{\prime} 35.24^{\prime \prime}$ & $45^{\circ} 02^{\prime} 50.53^{\prime \prime}$ & 1354 & 8.41 & 14.2 & 0.249 \\
\hline & SHAH 2 & between Urmia City and the river outlet, $05 / 2016$ & 37³3'16.93" & $45^{\circ} 16^{\prime} 12.26^{\prime \prime}$ & 1276 & 7.83 & 16.9 & 3.40 \\
\hline \multirow[t]{6}{*}{ well } & SALEH ABAD & in "Amir's garden", 09/2017 & $\begin{array}{c}37^{\circ} 31^{\prime} 16.626 \\
"\end{array}$ & $45^{\circ} 10^{\prime} 52.812^{\prime \prime}$ & 1294 & 7.28 & 14.2 & 0.884 \\
\hline & KESH 1 & Kesh Tiban, 09/2017 & ( & $45^{\circ} 14^{\prime} 07.224 "$ & 1281 & 8.13 & 19.9 & 0.575 \\
\hline & GOLMAN 0 & close to GOLMAN coring site, $05 / 2016$ & $37^{\circ} 35^{\prime} 15.44^{\prime \prime}$ & $45^{\circ} 15^{\prime} 19.70^{\prime \prime}$ & 1278 & 7.35 & 15.3 & 1.18 \\
\hline & HAJILAR 1 & 1st after sampling SHAH 2, 05/2016 & $37^{\circ} 33^{\prime} 22.00^{\prime \prime}$ & $45^{\circ} 16^{\prime} 17.51^{\prime \prime}$ & 1277 & 6.29 & 15.4 & 3.12 \\
\hline & HAJILAR 2a & Double well - large well, 05/2016 & $37^{\circ} 33^{\prime} 09.07^{\prime \prime}$ & $45^{\circ} 16^{\prime} 08.95^{\prime \prime}$ & 1276 & 6.12 & 15.1 & 12.22 \\
\hline & HAJILAR 2b & Double well - small well, 05/2016 & 37³3'09.07" & $45^{\circ} 16^{\prime} 08.95^{\prime \prime}$ & 1276 & 6.63 & 16.2 & 12.39 \\
\hline \multirow[t]{13}{*}{ coring well } & GOLMAN 1 & $9 \mathrm{~m}$ deep, $05 / 2016$ & $37^{\circ} 35^{\prime} 35.86^{\prime \prime}$ & $45^{\circ} 16^{\prime} 26.77^{\prime \prime}$ & 1270 & 6.84 & 29.6 & 222.0 \\
\hline & GOLMAN 1 & $9 \mathrm{~m}$ deep, 09/2017 & $37^{\circ} 35^{\prime} 35.86^{\prime \prime}$ & $45^{\circ} 16^{\prime} 26.77^{\prime \prime}$ & 1270 & 6.05 & 30.1 & 227.0 \\
\hline & GOLMAN 2 & $14 \mathrm{~m}$ deep, $05 / 2016$ & $37^{\circ} 35^{\prime} 35.09^{\prime \prime}$ & $45^{\circ} 16^{\prime} 28.60^{\prime \prime}$ & 1270 & 5.80 & 29.2 & 219.0 \\
\hline & GOLMAN 2 & $14 \mathrm{~m}$ deep, 09/2017 & 37035'35.09" & $45^{\circ} 16^{\prime} 28.60^{\prime \prime}$ & 1270 & 5.80 & 31.8 & 217.0 \\
\hline & GOLMAN 5 & $5.25 \mathrm{~m}$ deep, 09/2017 & 37035'33.4" & $45^{\circ} 16^{\prime} 27.6^{\prime \prime}$ & 1270 & 6.04 & 26.6 & 222.0 \\
\hline & GOLMAN 3 & $14.2 \mathrm{~m}$ deep, presurized water, $05 / 2016$ & 37³5'33.09" & $45^{\circ} 16^{\prime} 31.20^{\prime \prime}$ & 1270 & 6.48 & 25.0 & 141.1 \\
\hline & GOLMAN 3 & $14.2 \mathrm{~m}$ deep, inside coring tubing, $05 / 2016$ & $37^{\circ} 35^{\prime} 33.09^{\prime \prime}$ & $45^{\circ} 16^{\prime} 31.20^{\prime \prime}$ & 1270 & 6.35 & 20.2 & 147.1 \\
\hline & GOLMAN 3 & $14.2 \mathrm{~m}$ deep, inside coring tubing, $09 / 2017$ & $37^{\circ} 35^{\prime} 33.09^{\prime \prime}$ & $45^{\circ} 16^{\prime} 31.20^{\prime \prime}$ & 1270 & 6.24 & 18.9 & 142.0 \\
\hline & GOLMAN 3 & $14.2 \mathrm{~m}$ deep, outside tubing, $05 / 2016$ & $37^{\circ} 35^{\prime} 33.09^{\prime \prime}$ & $45^{\circ} 16^{\prime} 31.20^{\prime \prime}$ & 1270 & 6.61 & 27.5 & 158.8 \\
\hline & GOLMAN 3 & $14.2 \mathrm{~m}$ deep, outside tubing, 09/2017 & 37³5'33.09" & $45^{\circ} 16^{\prime} 31.20^{\prime \prime}$ & 1270 & 6.29 & 19.1 & 140.0 \\
\hline & GOLMAN 4 & $0.6 \mathrm{~m}$ deep & $37^{\circ} 35^{\prime} 37.31 "$ & $45^{\circ} 16^{\prime} 38.38^{\prime \prime}$ & 1270 & & & \\
\hline & GOLMAN 6 & $8 \mathrm{~m}$ deep & 4 & $45^{\circ} 16^{\prime} 33.834^{\prime \prime}$ & 1270 & & & \\
\hline & GOLMAN 7 & $12.5 \mathrm{~m}$ deep, presurized water & $\begin{array}{c}37^{\circ} 35^{\prime} 28.746 \\
"\end{array}$ & $45^{\circ} 16^{\prime} 33.75^{\prime \prime}$ & 1270 & & & \\
\hline lake & GOLMAN & near coring GOLMAN 4, 05/2016 & $37^{\circ} 35^{\prime} 37.31^{\prime \prime}$ & $45^{\circ} 16^{\prime} 38.38^{\prime \prime}$ & 1270 & 8.02 & 21.3 & 207.0 \\
\hline
\end{tabular}


Table 2

812

813

814

815

Core Sample

Depth Analyze Nr Nature

${ }^{14} \mathrm{C}$ Age

Cal ${ }^{14} \mathrm{C}$ Age

(yr)

$\rightarrow^{13} \mathrm{C}$

816

817

G6 G6-4.40 4.40

(m)

(yr BP) (yr)

$(\text { cal yr BP })^{(*)}$

(yr) (\% PDB)

818

819

820

821

822

823

824

825

826

827

G6

$4.40 \quad$ I2553/B2304 $\quad$ OM

$17561 \quad 76$

21200

$210 \quad-24.20$

G7 $\quad$ G7-S2 $2.80 \quad 2.80$

$2.80 \quad$ I2218/B2097

G7-S3 $4.05 \quad 4.05 \quad$ I2525/B2297

G7-S8 $12.46 \quad 12.46 \quad$ I2524/B2301 Charcoal 25591

Charcoal $4734 \quad 22$

5520

$100-26.50 /-13.50$

OM $\quad 15088 \quad 66$

18340

$\begin{array}{ll}190 & -25.30\end{array}$

G5 G5 2.34 2.34 I2141/B2087

Charcoal 4343

$\begin{array}{llll}66 & 29700 & 360 & -24.60\end{array}$

$\begin{array}{lll}\text { G5 } 3.66 & 2.66 & \text { I2142/B2088 }\end{array}$

Charcoal $4394 \quad 22$

4900
4950

$\begin{array}{ll}60 & -14.50 \\ 65 & -25.50\end{array}$

$\left({ }^{*}\right)$ Reimer et al, 2013. IntCal13 and MARINE13 radiocarbon age calibration curves 0-50000 years cal BP. Radiocarbon, 55(4). DOI: $10.2458 /$ azu_js_rc.55.16947

828

829

830

831

832

833 
834 Figure 1

a)

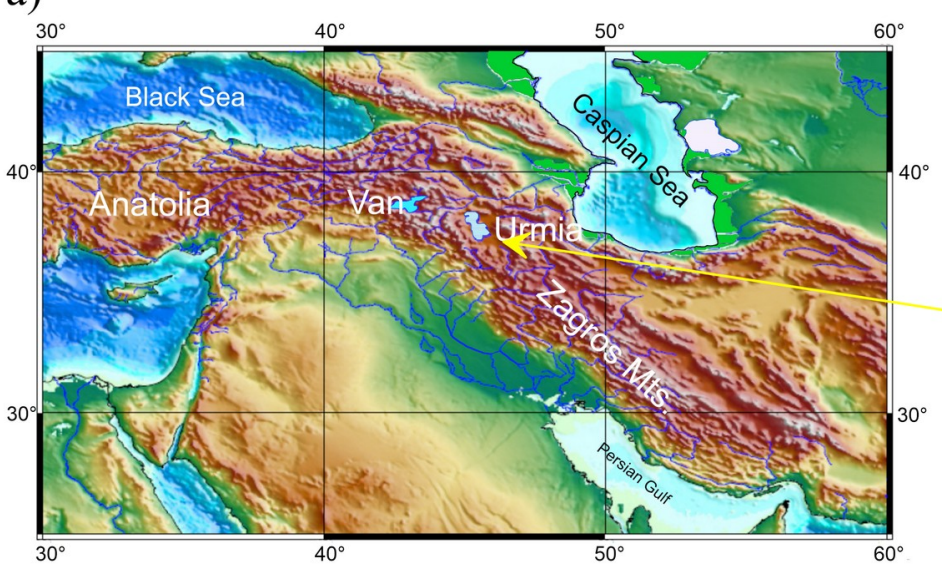

c)

$45^{\circ}$

$46^{\circ}$

$47^{\circ}$

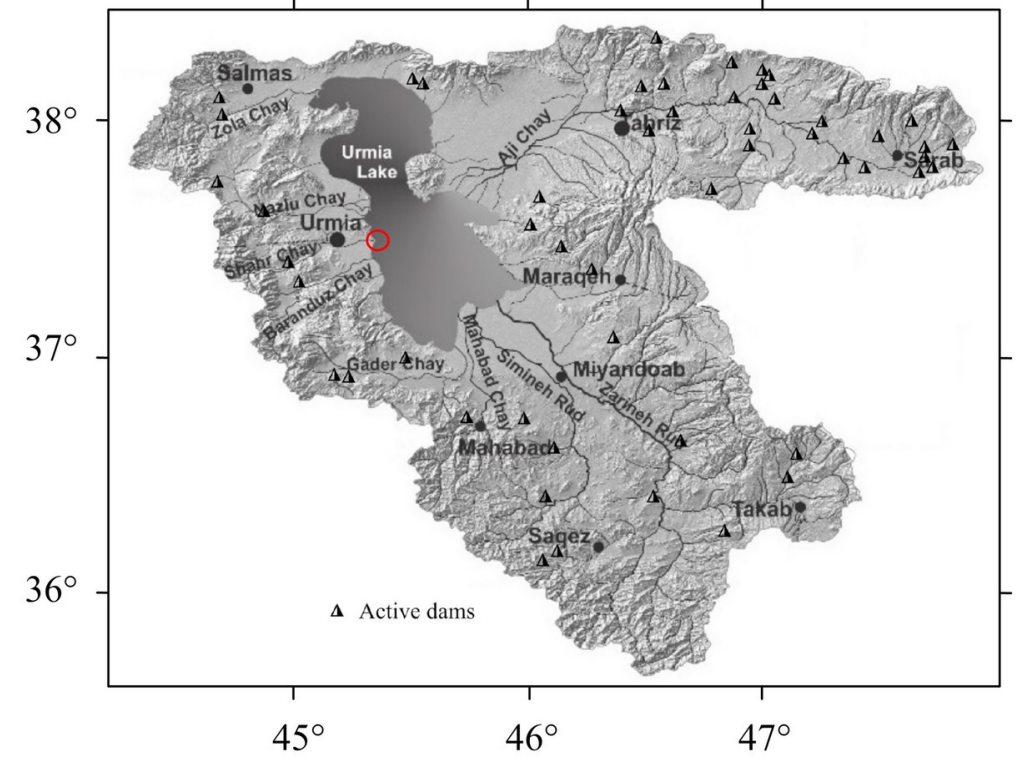

b)

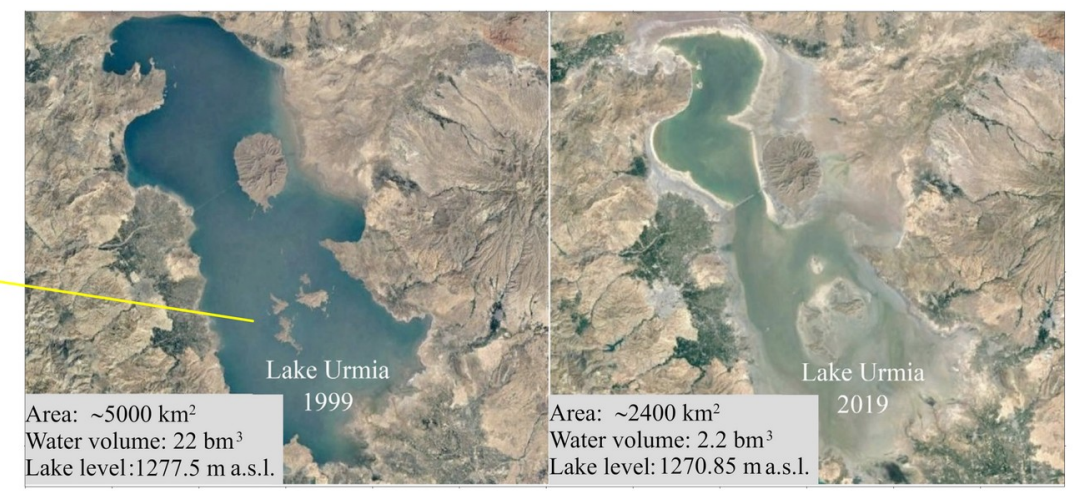

d)

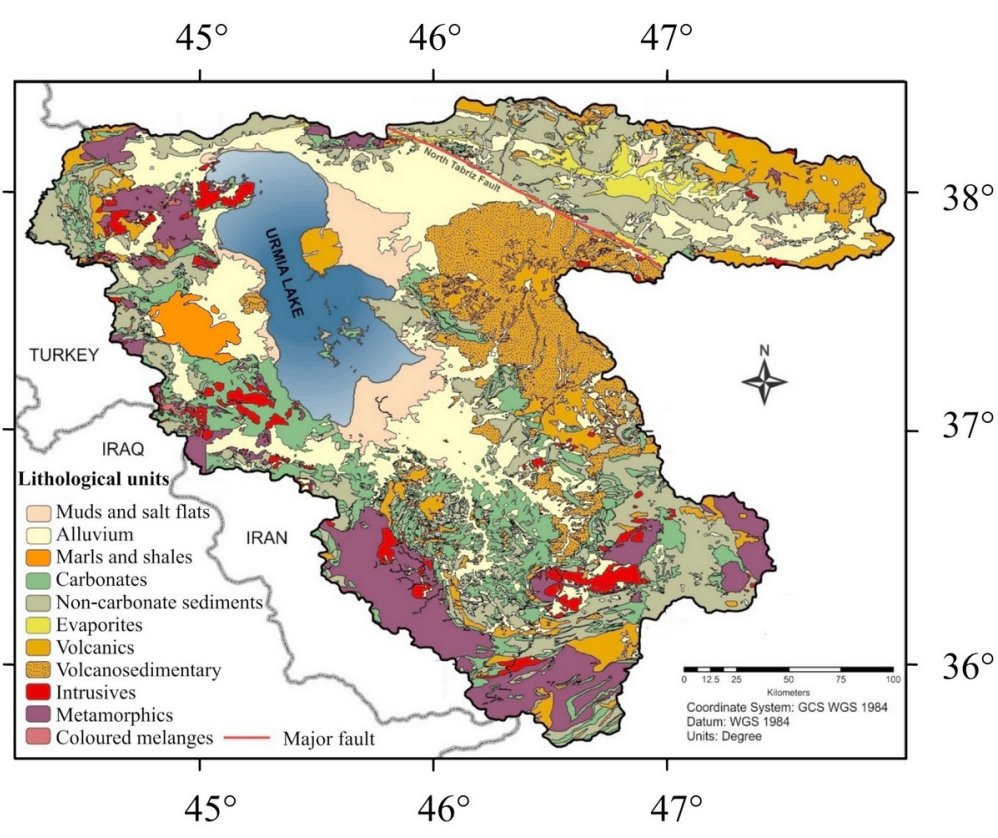


Figure 2

a)

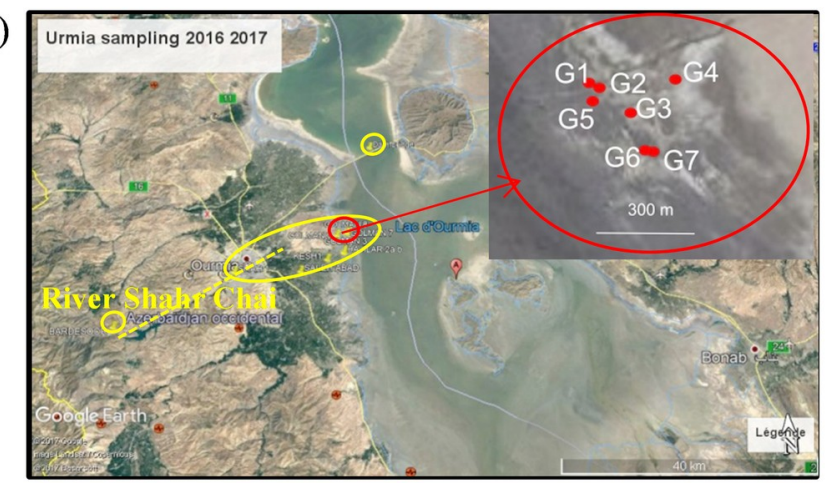

c)

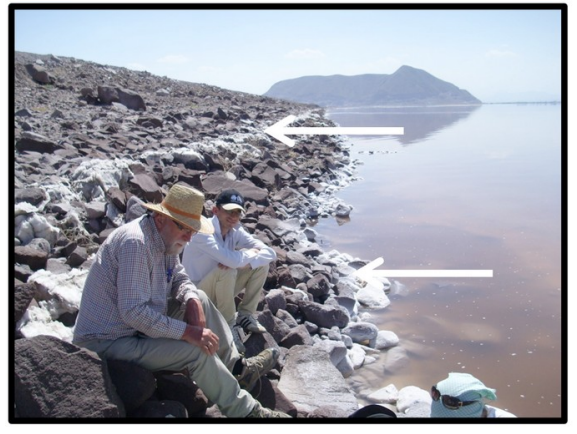

e)
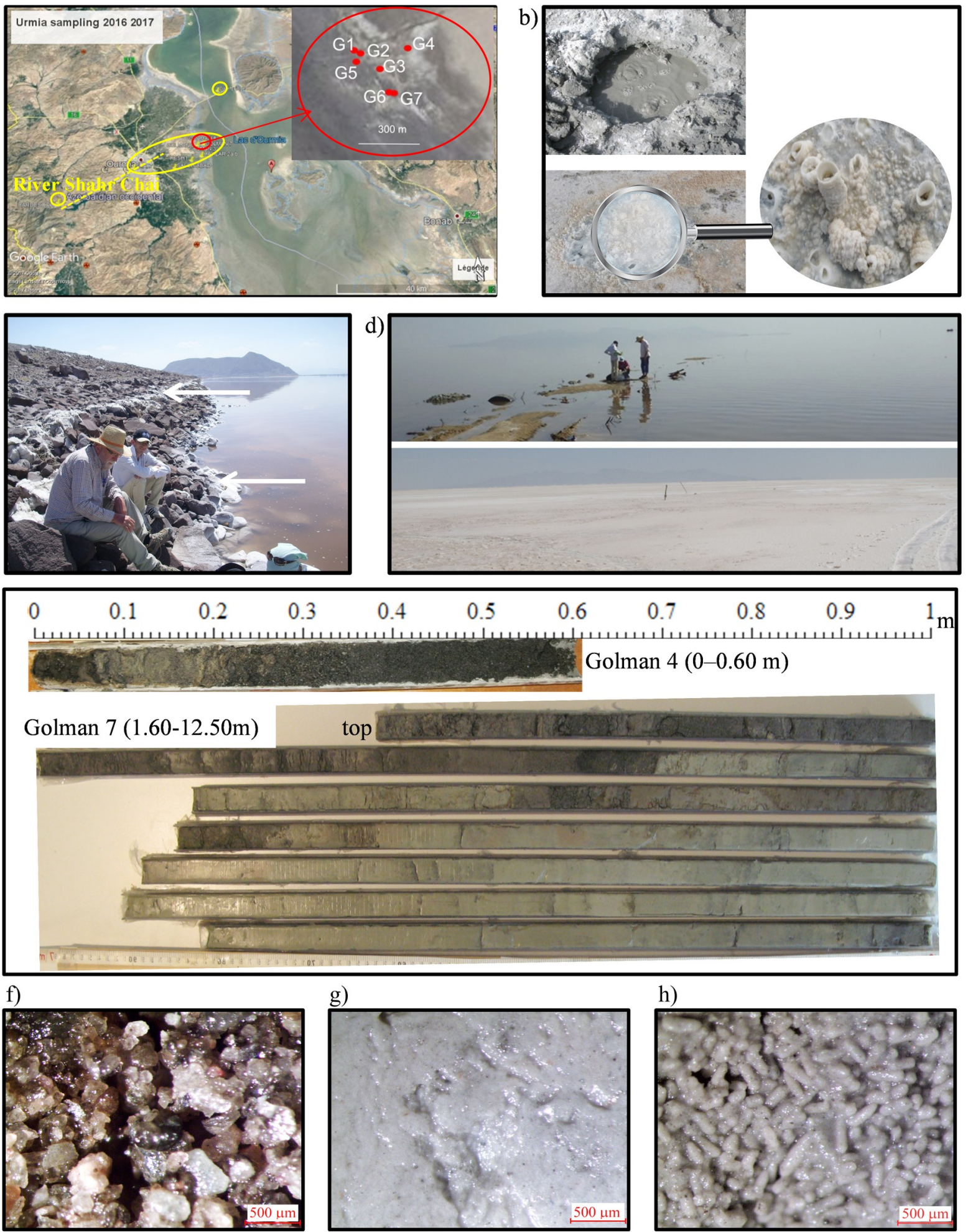

g)

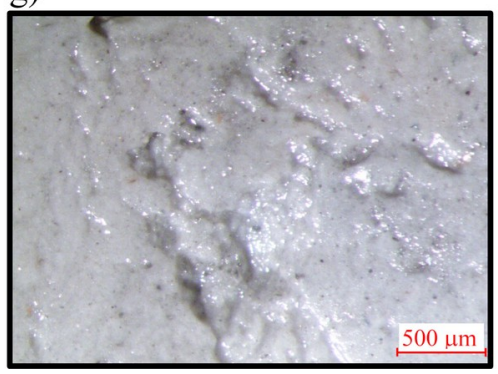

h)

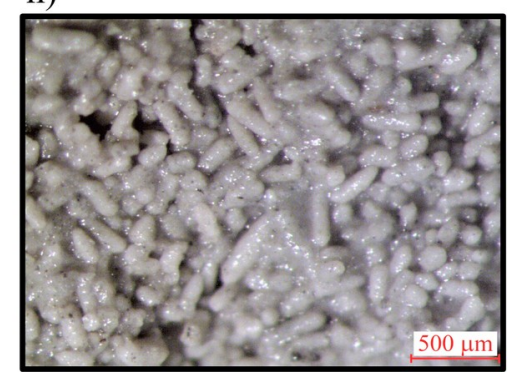


Figure 3

a)

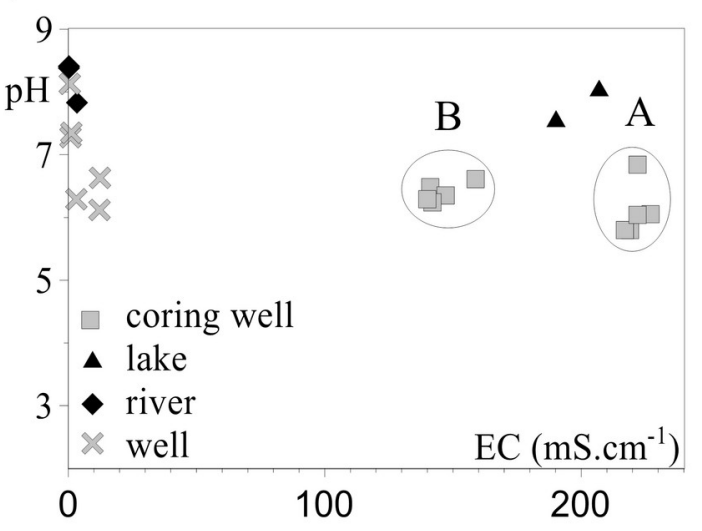

c) Golman 7; $4.10 \mathrm{~m}$

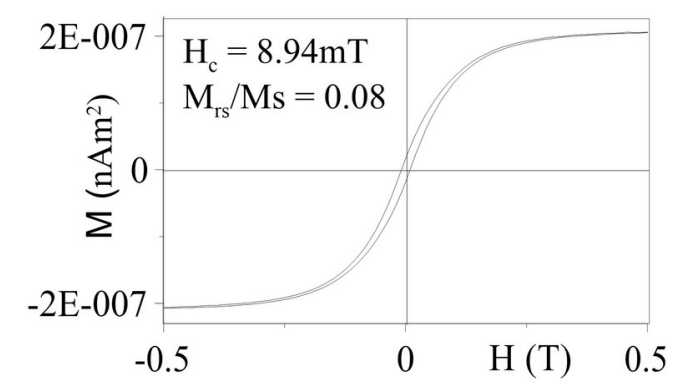

e) Golman 5; $0.53 \mathrm{~m}$

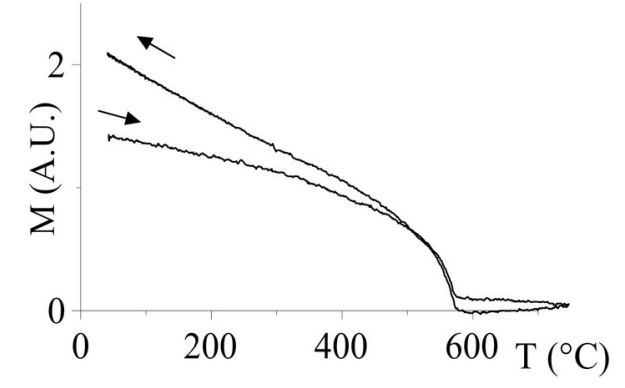

b)

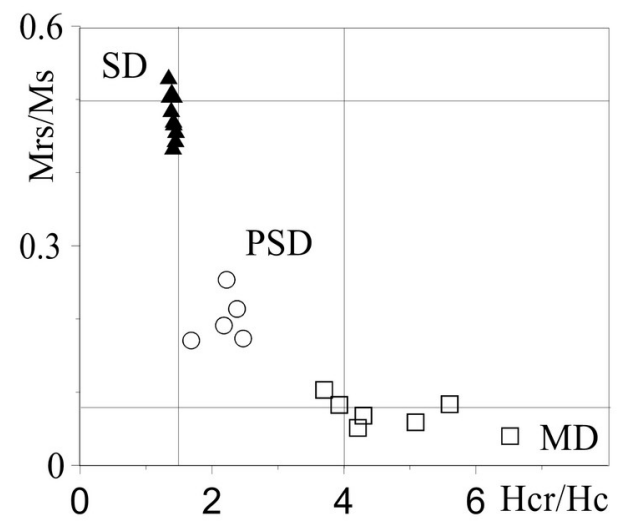

d) Golman 7; $12.45 \mathrm{~m}$

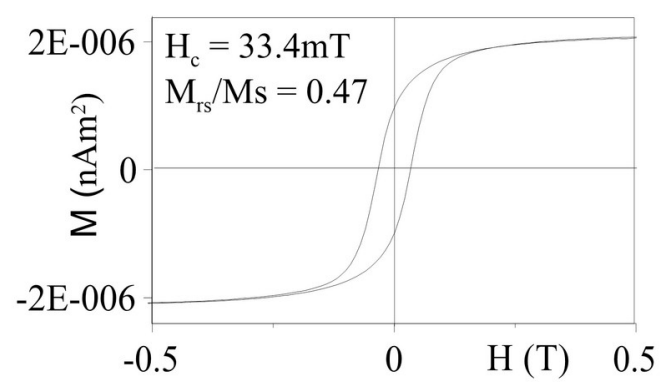

f) Golman 7; $2.85 \mathrm{~m}$

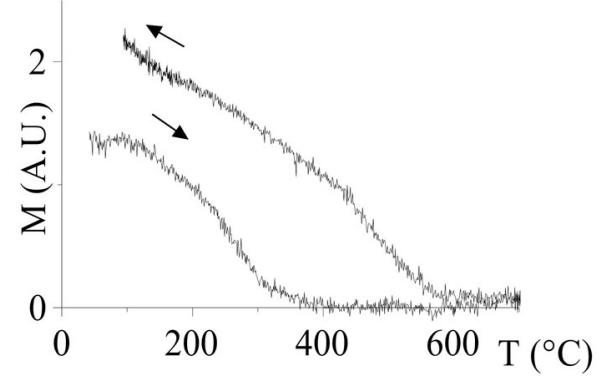

g)

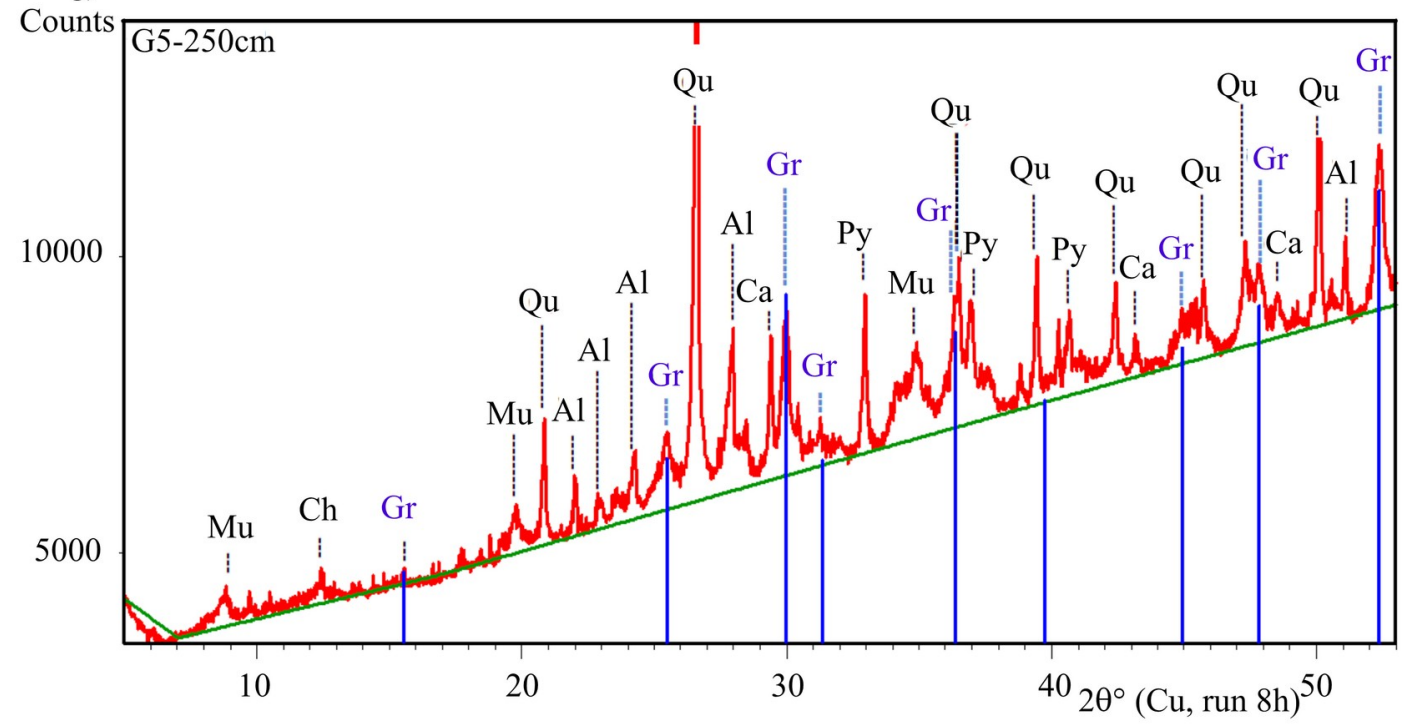


a) Golman 4

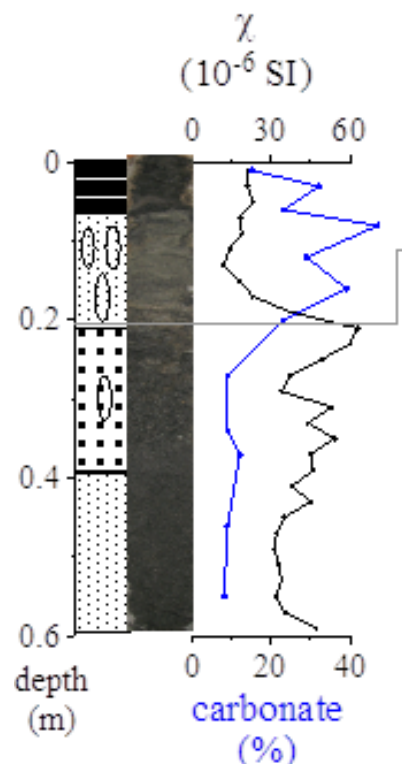

lithology

\begin{tabular}{|c|c|}
\hline & sand \\
\hline ::::::: & coarse sand \\
\hline $\begin{array}{lll}0 & 0 & 0 \\
\end{array}$ & fecal pelets \\
\hline
\end{tabular}

dating level in the core

* corkscrew $=$ modern sediment

$\rightarrow{ }^{14} \mathrm{C}$ AMS dating

b) Golman 5
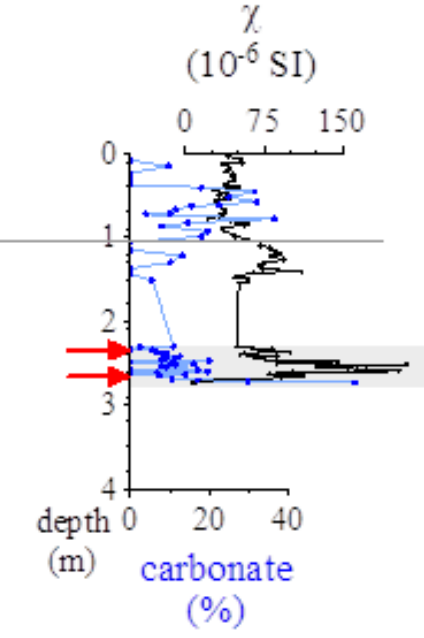

(\%) c) Golman 3

d) Golman 7

e) Golman 6

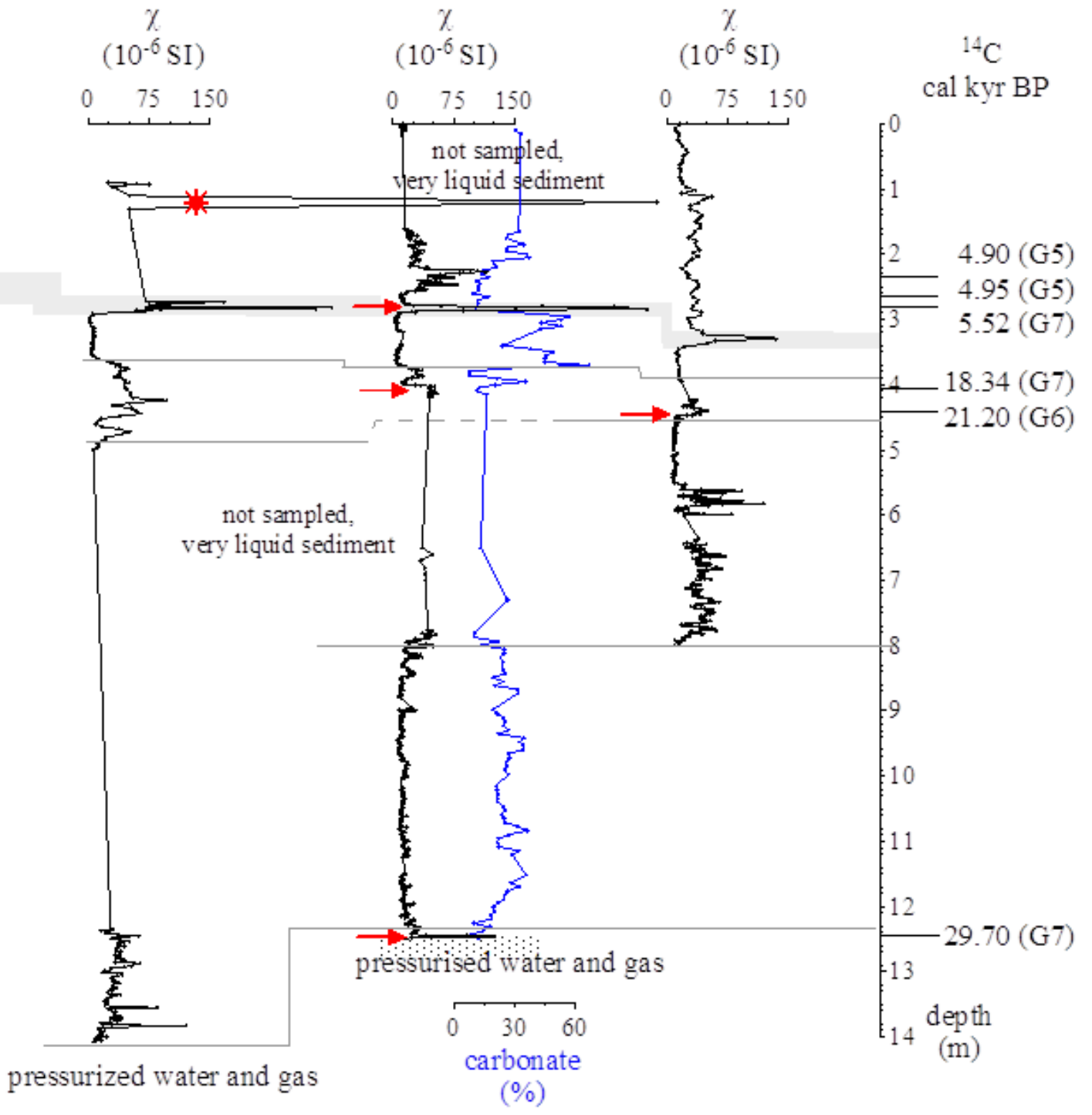


$847 \quad$ Figure 5

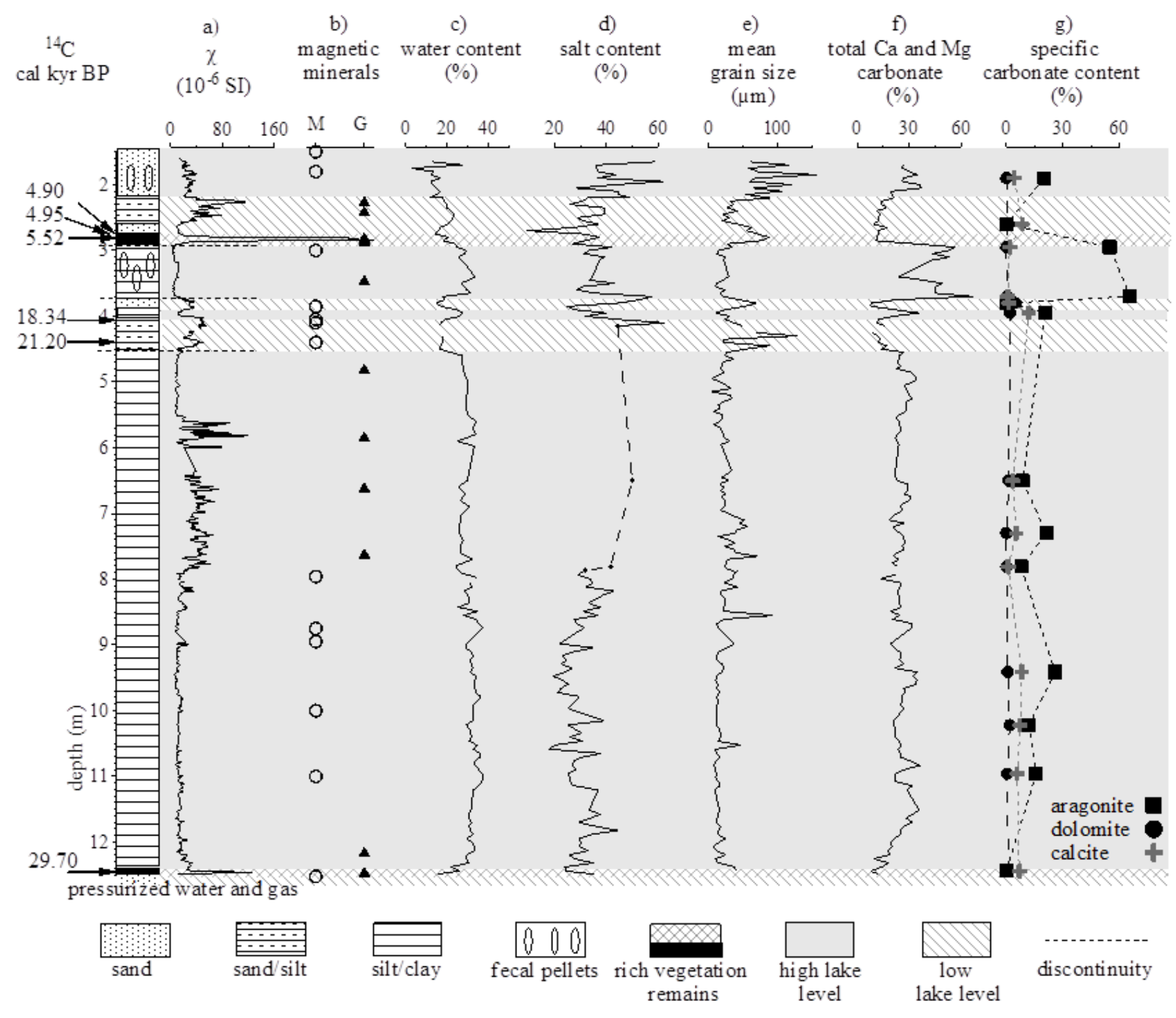

